University of Pennsylvania Carey Law School

Penn Law: Legal Scholarship Repository

Faculty Scholarship at Penn Law

1985

\title{
Causing the Conditions of One's Own Defense: A Study in the Limits of Theory in Criminal Law Doctrine
}

Paul H. Robinson

University of Pennsylvania Carey Law School

Follow this and additional works at: https://scholarship.law.upenn.edu/faculty_scholarship

Part of the Constitutional Law Commons, Criminal Law Commons, Ethics and Political Philosophy Commons, Jurisprudence Commons, and the Public Law and Legal Theory Commons

\section{Repository Citation}

Robinson, Paul H., "Causing the Conditions of One's Own Defense: A Study in the Limits of Theory in Criminal Law Doctrine" (1985). Faculty Scholarship at Penn Law. 623.

https://scholarship.law.upenn.edu/faculty_scholarship/623

This Article is brought to you for free and open access by Penn Law: Legal Scholarship Repository. It has been accepted for inclusion in Faculty Scholarship at Penn Law by an authorized administrator of Penn Law: Legal Scholarship Repository. For more information, please contact PennlawIR@law.upenn.edu. 


\section{VIRGINIA LAW REVIEW}

VOLUME 71

FEBRUARY 1985

NUMBER 1

\section{CAUSING THE CONDITIONS OF ONE'S OWN DEFENSE: A STUDY IN THE LIMITS OF THEORY IN CRIMINAL LAW DOCTRINE*}

\section{Paul H. Robinson**}

$\mathrm{O}$

NE widely-stated goal of criminal law theory is to create the set of rules that best implements our collective sense of justice. To reach this goal, the theorist continuously adjusts his theory so that it generates rules that better reflect our fundamental notions of justice. ${ }^{1}$ These rules, moreover, must function as workable doctrine, which in the context of criminal law means precise statutory provisions. ${ }^{2}$

* This article is based on a paper presented to the German-Angloamerican Workshop on Basic Problems in Criminal Law Theory, held at the Max Planck Institüt für Ausländisches und Internationales Strafrecht, Freiburg, West Germany, July 1-21, 1984. The author wishes to acknowledge the contributions of J. Grall Robinson to this article.

** Professor of Law, Rutgers University School of Law-Camden. B.S. 1970, Rensselaer Polytechnic Institute; J.D. 1973, University of California at Los Angeles; LL.M. 1974, Harvard; Dipl. Leg. St. 1976, Cambridge.

${ }^{1}$ Indeed, some would extend the process beyond criminal law. See, e.g., C. Radcliffe, The Law and its Compass 63-64 (1960) ("Every system of jurisprudence needs . . a constant preoccupation with the task of relating its rules and principles to the fundamental moral assumptions of the society to which it belongs.").

2 This statement is especially true in the United States, where in many states only offenses defined by statute are punishable. See, e.g., Colo. Rev. Stat. \$ 18-1-104(3) (1978); Del. Code Ann, tit. 11, § 202(a) (1979); Hawaii Rev. Stat. § 701-102(1) (1976); Ill. Ann. Stat. ch. 38, § 1-3 (Smith-Hurd Supp. 1984-1985); La. Rev. Stat. Ann. § 14:7 (West 1974); Mont. Code Ann. § 45-1-104(2) (1983); N.J. Stat. Ann. § 2C:1-5(a) (West 1982); cf. Krulewitch v. United States, 336 U.S. 440, 456-57 (1949) (Jackson, J., concurring) (federal criminal prosecutions must be based on statutory authority). Similarly, many states abolish all commonlaw crimes. See, e.g., Colo. Rev. Stat. § 18-1-104(3) (1978); Wis. Stat. Ann. § 939.10 (West 1982); Wyo. Stat. § 6-1-102 (1983). In any event, even if existing common-law offenses may be enforced, the commonly accepted "principle of legality" forbids the creation of new ones. 
It is this process of theoretical refinement and translation that is the topic of this article. Can good theory generate results that approximate our collective sense of justice? Can the theoretical refinements be translated into workable statutory provisions? What limits the success of the translation?

As a case study, this article offers a theory to resolve one of the more troublesome areas of criminal law: cases where an actor is in some way responsible for bringing about the conditions of his own defense, such as by provoking another's use of unlawful force against him or by causing his own intoxication. As Part I illustrates, current law governing such instances is inadequate. It is inconsistent, frequently irrational, and is a poor approximation of our collective sense of justice. Part Il offers some basic theoretical principles to govern cases of causing the conditions of one's own defense. These principles are consistent with well-accepted principles of liability and exculpation, and they generate results that accord well with our notions of justice. Nevertheless, dramatic improvement in the law can be realized only if the theory can be implemented through workable doctrine, as expressed in statutes. The statutes proposed here, in fact, face troublesome questions about complexity and difficulties of proof.

Part III examines the extent of these problems and offers possible solutions. The most promising solutions, however, have their own problems of constitutional infirmity. Ultimately, then, the confines of the American criminal justice system limit the translation of good theory into workable doctrine.

\section{Current Law Treatment of an Actor Who Brings About the Conditions of His Own Defense}

Current law generally takes one of several approaches in dealing with an actor who brings about the conditions of his own defense, and commonly addresses such a situation in relation to five types of defenses: the lesser evils justification, ${ }^{3}$ the self-defense justifica-

See generally Jeffries, Legality, Vagueness, and the Construction of Penal Statutes, 71 Va. L. Rev. (March 1985) (forthcoming).

${ }^{3}$ A justification defense exculpates an actor who satisfies all elements of an offense definition under circumstances that create a benefit that outweighs the harm of the offense-either because a greater harm is avoided or because a greater social interest is furthered. "Lesser evils" or "choice of evils" is perhaps the most basic justification defense. It involves balancing the harm caused against the harm avoided. An actor who destroys one 
tion, ${ }^{4}$ the duress excuse, ${ }^{5}$ the general intoxication excuse, ${ }^{6}$ and the intoxication-based failure of proof "defense."

\section{A. Withholding a Defense upon Any Causal Contribution}

\section{Several jurisdictions deny a lesser evils defense whenever an ac-} tor contributes in any way, even without fault, to causing the need for the justified conduct. ${ }^{8}$ Thus, if an actor sets a firebreak to min-

house and prevents a fire from consuming a whole town, for example, might have a lesser evils defense. See generally Robinson, Criminal Law Defenses: A Systematic Analysis, 82 Colum. L. Rev. 199, 213-14 (1982) (discussing lesser evils) [hereinafter cited as Robinson, A Systematic Analysis].

4 Self-defense, like lesser evils, involves a balancing of harms. In addition to the immediate objective harms created and averted, the harm to the social order inherent in unjustified aggression is significant for this defense. Such abstract interests explain society's willingness to justify one who kills an attacker, even though the immediate interests-a life for a life-seem evenly balanced. See generally Robinson, A Systematic Analysis, supra note 3, at 214-15 (discussing self-defense, defense of others, and defense of property).

- An excuse defense exculpates an actor who has satisfied all the elements of an offense and who has caused net harm but who, due to a confirmable disability that creates an excusing condition, cannot be considered responsible for his conduct. There are four types of excusing conditions, i.e., conditions that society recognizes as rendering an actor blameless: the conduct is not the product of his effort or determination; the actor does not perceive the physical nature or consequences of his conduct; the actor does not know his conduct is wrong; and the actor's ability to control his conduct is so impaired that he cannot be fairly held accountable for it. The duress defense, for example, is available to an actor who, due to a state of coercion brought about by a threat that a reasonable person could not resist, cannot sufficiently control his conduct so as to be held accountable for it. See generally Robinson, A Systematic Analysis, supra note 3, at 221-29 (discussing excuse defenses).

6 Just as a state of coercion may bring about an excusing condition, supra note 5 , intoxication may so affect an actor's perception, cognition, or control, as to render the actor blameless for his conduct. For example, a drunken person may kill a friend because of the alcohol-induced belief that God commanded him to do so or because the alcohol impaired his ability to control his actions. In both cases, the actor knew that he was killing someone, but society may deem his behavior to be insufficiently blameworthy to punish him. Insanity is another disability that warrants an excuse defense on the basis of similar excusing conditions. Although the excusing condition is the central reason for the excuse defense, these defenses are often categorized according to the disability and not the resulting impairment. See generally Robinson, A Systematic Analysis, supra note 3, at 221-29 (discussing excuse defenses).

7 A failure of proof "defense," unlike justifications and excuses, does not provide a ground of defense that is independent of the offense definition. A failure of proof defense is nothing more than the absence of one or more required elements of the offense. Although the state has the burden of proving the existence of each element of the offense, the defendant may wish to introduce particular evidence to rebut the prosecution's case, for example, evidence of intoxication to raise a doubt as to whether the defendant acted with the culpability required by the offense definition.

B For example, the Colorado lesser evils statute permits necessary and proportional re- 
imize the harm that would otherwise be caused by a forest fire that a defective muffler on his camper started, these jurisdictions would deny this actor a justification defense to a charge of arson ${ }^{9}$ for burning the firebreak.

Many self-defense statutes similarly appear to withhold a justification defense on the basis of any causal contribution. One such statute denies the defense if the actor "brings on a difficulty."10 Others deny the defense if the actor "provoked the other's use or attempted use of unlawful force" in the same encounter. ${ }^{11}$ This lat-

sponses to threats of injury only when the situation was "occasioned or developed through no conduct of the actor." Colo. Rev. Stat. \$ 18-1-702(1) (1978); see also State v. Diana, 24 Wash. App. 908, 913-14, 604 P.2d 1312, 1316 (1979) (defense unavailable where the actor brought about the compelling circumstances); cf. P.R. Laws Ann. tit. 33, § 3096 (1983) (defense available only if the actor did not provoke the danger).

One might argue that a court, or at least some courts, would read into the Colorado statute some "fault" requirement and that, in the end, the statute adequately "does the job." This sort of argument, however, only shows the sad state of substantive criminal law theory and doctrine in the United States. First, that a court might read in a fault requirement only confirms the criticism of the statute: that it fails to include a fault requirement. Second, to assume that a court will, without fail, essentially rewrite a statute that is clear on its face is to assume too much. Third, to conclude that a statute has "done its job" when it has been saved by such judicial legislation is to expect very little from statutes. The most invidious effect of such a view of statutes is that if we expect inadequate, incomplete, and improper statutes, we will receive inadequate, incomplete, and improper statutes. That is exactly what we have in the United States, compliments of this sort of mindless acceptance of inadequate codifications.

One need not be a criminal law purist to find offensive this indifference to the quality of criminal law codifications. Anglo-American systems have committed themselves to the legality principle, which requires, for a plethora of compelling reasons, a clear, precise, and written statement of the definition of offenses and all related rules of liability. Some of the rationales for the principle arise from concerns of faimess to the defendant, others from the concerns of improper delegation of legislative authority to the courts. See generally Robinson \& Grall, Element Analysis in Defining Criminal Liability: The Model Penal Code and Beyond, 35 Stan. L. Rev. 681, 682-85, 691 n.42, 712-13 (1983) [hereinafter cited as Robinson \& Grall, Element Analysis]. Yet American scholars, with a few commendable exceptions, blithely carry on with their acute preoccupation for intricate procedural rules but think nothing of statutes that must depend on a court to rewrite them to even begin approximat. ing the most basic requirements of rationality and justice.

- E.g., Colo. Rev. Stat. § 18-4-105(1) (1978) ("Fourth degree arson").

"La. Rev. Stat. Ann. $\$ 14: 21$ (West 1974) (also denies the defense to the "aggressor").

${ }^{1}$ Tex. Penal Code Ann. $\$ 9.31(b)(4)$ (Vernon 1974); accord Ariz. Rev. Stat. Ann. § 13 404(B)(3) (1978); Kan. Stat. Ann. § 21-3214(3) (1981). In a limited way, Illinois, Iowa, and Kansas consider an actor's culpability as to the provocation. These statutes treat an actor who intentionally provokes another's force with the intent of creating an excuse to use force differently from one who merely provokes. The intentional provoker may not regain the right to use force; the mere provoker may. See Ill. Ann. Stat. ch. 38, $\$ 7.4$ (b)-(c) (SmithHurd 1972); Iowa Code Ann. $§ 704.6(2)$, (3)(b) (West 1979); Ken. Stat. Ann. $\$ 21-3214(2)$ - 
ter exclusion appears to disregard both the actor's lack of a culpable state of mind as to the provocation ${ }^{12}$ and the unjustified response to his provocation. ${ }^{13}$ The exclusion appears to bar the defense even when the actor's provoking conduct does not constitute an unjustified attack. ${ }^{14}$ For example, if the actor's choice of

(3) (1981); see also infra note 13 (discussing provisions that allow a provoker to regain the right of self-defense).

Some jurisdictions withhold the self-defense justification from the initial provoker only if the victim responds with nondeadly force. See, e.g., Fla. Stat. Ann. § 776.041(2)(a) (Harrison 1981) (initial provoker may use force if he reasonably believes he is in danger of death or great bodily harm and has exhausted all reasonable means of escape); Ill. Ann. Stat. ch. 38, \& 7-4(c)(1) (Smith-Hurd Supp. 1972) (same).

12 Case law often uses broad language that purports to exclude any defendant who "provokes" the use of force, but the exclusion seems only to be applied against actors who are to some degree at fault as to whether their conduct would provoke force. See, e.g., Dabney v. State, 113 Ala. 38, 21 So. 211 (1897) (defendant's sexual intercourse with victim's wife found to be provocation sufficient to deny self-defense); Daniel v. State, $187 \mathrm{Ga} .411,1$ S.E.2d 6 (1939) (defendant's armed attempt to recover money from victim was sufficient provocation to deny self-defense). In State v. Jackson, 94 Ariz. 117, 382 P.2d 229 (1963), the defendant returned to a clubroom where he previously had an argument while shooting dice with the person he subsequently killed. The lower court viewed this as sufficient provocation to bar the defendant's plea of self-defense during the subsequent altercation. The Arizona Supreme Court reversed the conviction, holding that "[b]efore an act may cause forfeiture of the fundamental right of self-defense it must be willingly and knowingly calculated to lead to conflict." Id. at 122,382 P. 2 d at 232 .

13 Most of the statutes cited supra note 11 restore the right to act in self-defense if the actor, after his initial provocation, effectively withdraws and communicates his withdrawal to his assailant and the assailant nevertheless continues the use of force. See, e.g., Ariz. Rev. Stat. Ann. $\S 13-404(B)(3)$ (1978); Fla. Stat. Ann. $\S 776.041(2)$ (b) (Harrision 1981); Ill. Ann. Stat. ch. 38, § 7-4(c)(2) (Smith-Hurd 1972); Kan. Stat. Ann. $\$ 21-3214(3)(b)(1981)$. In short, the defense revives if the provoker is met with a response that is unjustified because it violates the necessity requirement. It is not clear why the defense should not similarly revive if the response is unjustified because it violates the proportionality requirement, i.e., because the responder uses more force than is reasonable in response to the threat or provocation. Iowa revives the defense either if the provoker withdraws or if the response to his provocation is "grossly disproportionate" and the provoker reasonably believes that he is in imminent danger of death or serious physical injury. Iowa Code Ann. $\$ 704.6(3)$ (West 1979).

${ }^{14}$ It is hard to understand why the provoker should lose the right of self-defense when he is not culpable and when his conduct is too trivial to give rise to a right of self-defense for the person whom he provokes. For example, Texas explicitly provides that the use of force in response to verbal provocation is unjustified, Tex. Penal Code Ann. $\$ 9.31(b)(1)$ (Vernon 1974), yet the actor who is a verbal provoker cannot defend himself against force used in response to his verbal provocation. Id. $\S 9.31(b)(4)$. Thus, the verbal provoker cannot defend himself against an unjustified attack; usually only justified conduct is given such protected status. See Robinson, A Systematic Analysis, supra note 3, at 274-80. For a discussion of a basis for liability where a provoker culpably causes an attack by engaging in otherwise lawful conduct, see infra section II(E). 
paint color for his house so upsets his neighbor as to provoke an attack, the actor would presumably be left without the right to defend himself. Although one might hope that courts would interpret the statutory term "provoke" to require some culpability, this hope is of little comfort to the theorist or draftsman who seeks to implement rational criminal law through clear doctrine. ${ }^{15}$

Rather than using the term "provoke," some jurisdictions deny self-defense if the actor is the "initial aggressor." 16 "This rule allows

15 See supra discussion note 8 .

18 See, e.g., Ala. Code $\S 13$ A-3-23(c)(2) (1982); Alaska Stat. § 11.81.330(a)(3) (1983); Am. Samoa Code $\S 46.3305$ (1981); Ark. Stat. Ann. § 41-506(2)(b) (1977); Colo. Rev. Stat. § 18 1-704(3)(b) (1978); Conn. Gen. Stat. Ann. § 53a-19(c)(2) (West 1972); Ga. Code Ann. § 16 3-21(b)(3) (1984); Ind. Code Ann. § 35-41-3-2(d)(3) (Burns Supp. 1984); Ky. Rev. Stat. $\S 503.060(3)$ (1975); Me. Rev. Stat. Ann. tit. 17-A, § 108(1)(B) (1983); Mo. Rev. Stat. $\S 563.031 .1(1)$ (1978); N.H. Rev. Stat. Ann. § 627:4(I)(b) (1974); N.Y. Penal Law § 35.15(1)(b) (McKinney 1975); N.D. Cent. Code $\S 12.1-05-03(2)$ (b) (1976); Or. Rev. Stat. § 161.215(2) (1983); Utah Code Ann. § 76-2-402(2)(c) (1978); cf. Idaho Code $\$ 18-4009(3)$ (1979) (self-defense for homocide denied if the actor was the "assailant").

As is the case with the "provoker" provisions, see sources cited supra note 13 , the initial aggressor may typically regain the defense if he withdraws from the encounter and effectively communicates his withdrawal. See Ala. Code $\S 13 \mathrm{~A}-3-23(\mathrm{c})(2)(1982)$; Ark. Stat. Ann. $\S 41-506(2)(b) \cdot(1977)$; Colo. Rev. Stat. $\$ 18-1-704(3)$ (b) (1978); Conn. Gen. Stat. Ann. $\S 53 a-19$ (c)(2) (West 1972); Ga. Code Ann. § 16-3-21(b)(3) (1984); Ind. Code Ann. § 35-413-2(d)(3) (Burns Supp. 1984); Ky. Rev. Stat. $\$ 503.060(3)$ (b) (1975); Me. Rev. Stat. Ann. tit. 17-A, §108(1)(B) (1983); N.H. Rev. Stat. Ann. §627:4(I)(b) (1974); N.Y. Penal Law $\S 35.15(1)$ (b) (McKinney 1975); N.D. Cent. Code $\S 12.1-05-03(2)$ (b) (1976); Or. Rev. Stat. $\S 161.215(2)$ (1983); Utsh Code Ann. $\$ 76-2-402$ (2)(c) (1978). This solution for dealing with culpability in causing suffers, however, from the same defects as it does in the context of the provoker provisions: the defense does not revive if the response is merely disproportionate. See supra note 13 .

In addition, each of the jurisdictions above distinguishes the provoker who uses force with the intent of establishing a defense for his use of force from the actor who is merely an initial aggressor. The former may never regain the right of self-defense. See Ala. Code $\S 13$ A-3-23(c)(1) (1982); Ark. Stat. Ann. $\S 41-506(2)$ (a) (1977); Colo. Rev. Stat. § 18-1704(3)(a) (Supp. 1984); Conn. Gen. Stat. Ann. § 53a-19(c)(1) (West 1972); Ga. Code Ann. $\S 16-3-21$ (b)(1) (1984); Ind. Code Ann. $\$ 35 \cdot 41-3-2$ (d)(2) (Burns Supp. 1984); Ky. Rev. Stat. $\$ 503.060(2)$ (1975); Me. Rev. Stat. Ann. tit. 17-A, 108(1)(A) (1983); N.H. Rev. Stat. Ann. $\S 627: 4(1)(a)$ (1974); N.Y. Penal Law $\$ 35.15(1)$ (a) (McKinney 1975); N.D. Cent. Code $\S$ 12.1-05-03(2)(a) (1976); Or. Rev. Stat. $\S 161.215(1)$ (1983); Utah Code Ann. $\$ 76-2-$ 402(2)(a) (1978); see also statutes cited supra note 11 (intentional provoker always denied the defense; mere provoker regains upon withdrawal). Contra Alaska Stat. $\S \S 11.81 .330$ (b), .335(a) (1983) (treating both the initial aggressor and the intentional provoker identically; both may regain the defense).

The distinction between the actor who intentionally provokes and the actor who is merely the initial aggressor is clearly based on culpability. The distinction suggests that the less stringent "initial aggressor" standard, discussed in the first paragraph of this note, is not dependent upon fault. 
the actor to retain the defense if his initial provocation falls short of physical force, as in the house-paint hypothetical. It still fails, however, to consider the actor's culpability in committing his "aggression" and to account for excessive and thus unjustified responses to the actor's initial aggression. When an actor pushes another person, either accidentally or deliberately so as to board a bus first, he would apparently be denied a right of self-defense under this statute when the other rider responds by shooting the actor. ${ }^{17}$

The same approach-barring the defense if the actor has contributed in any way to causing the conditions of his defense--is frequently taken for excuse defenses as well. Most jurisdictions bar a general intoxication excuse if the intoxication was "voluntary."18 Several courts have defined voluntary intoxication so broadly as not to require any culpability as to causing the defense conditions. ${ }^{19}$ Thus, the intoxicated actor who mistakenly believes his friend to be an attacker and shoots him would not receive a defense, ${ }^{20}$ even if he could show that he would not have made the

17 Cf. State v. Potter, 295 N.C. 126, 144, 244 S.E.2d 397, 409 (I978) (defining "aggressor" as one who "aggressively and willingly enters into a fight without legal excuse or provocation" (emphasis added)).

18 See 2 P. Robinson, Criminal Law Defenses $\S 176(\mathrm{~b})$ (1984) (discussing voluntarily causing one's intoxication) [hereinafter cited as P. Robinson, Criminal Law Defenses]. Some courts, however, would permit a voluntary intoxication defense when the intoxication causes temporary insanity. See, e.g., Burns v. State, 591 S.W.2d 780, 783-84 (Tenn. Crim. App. 1979).

19 This is most frequently done through a narrow definition of what will constitute "involuntary" intoxication. See, e.g., Easter v. District of Columbia, 209 A.2d 625, 627 (D.C. 1965) (involuntary intoxication is without consent or through force or fraud, but cannot be caused by chronic alcoholism), modified, 361 F.2d 50 (D.C. Cir. 1966) (in cases of public drunkenness, chronic alcoholism constitutes involuntary intoxication; relying on alternate statutory, common law, and constitutional grounds); Commonwealth v. Sheehan, 5 Mass. App. Ct. 754, 759 n.4, 370 N.E.2d 1021, 1024 n.4 (1977) (intoxication is involuntary if consumption is forced or the substance is secretly administered), aff $\mathrm{d}$ on other grounds, 376 Mass. 765, 77I, 383 N.E.2d 1115, 1119 (1978) (declining to address the general issue of intoxication as an excuse). As a result, innocent mistakes apparently do not establish involuntary intoxication.

${ }^{20}$ See Springfield v. State, 96 Ala. 81, 11 So. 250 (1892); Golden v. State, 25 Ga. 527 (1858) (both holding that a claim of self-defense is not available if the actor's mistaken belief in the need for force is due to voluntary intoxication). The original statement in Golden referred only to drunkenness, with no qualification as to voluntariness, but the case has later come to be understood as referring to voluntary intoxication. See, e.g., Estes v. State, $55 \mathrm{Ga}$. 31, 32-33 (1875). The Estes court mentioned, although it did not quote, a provision of the Georgia criminal code that reads "[d]runkenness shall not be an excuse for any crime or misdemeanor, unless such drunkenness was occasioned by the fraud, artifice, or contrivance of other person or persons, for the purpose of having a crime perpetrated 
mistake but for his intoxication and that he was not culpable as to becoming intoxicated. He would be convicted of intentional homicide; he intended to kill. Similarly, some jurisdictions do not allow a defendant to use such voluntary intoxication as a failure of proof defense to show that he lacked the requisite culpable state of mind. ${ }^{21}$

All these causing-the-conditions provisions are clearly inappropriate. Where an actor causes the conditions of his defense but does so blamelessly, there is little justification for taking away his defense. ${ }^{22} \mathrm{He}$ is no more blameworthy for causing the conditions of his defense than is the actor who has made no causal contribution.

\section{B. Withholding a Defense upon a Minimum Culpability as to Causing the Defense Conditions}

A somewhat more discriminating approach is to bar a defense whenever the actor is at fault, i.e., at least negligent, in bringing about the conditions of his defense. In self-defense, ${ }^{23}$ for example,

"Act of Dec. 23, 1833, 1st div., \$ 9, $1851 \mathrm{Ga}$. Laws 778, 779 (Cobb). This position is even more restrictive than those cited supra note 19 . See generally W. LaFave \& A. Scott, Handbook on Criminal Law § 45, at 347 (1972) (self-defense is not available to the voluntarily intoxicated actor because he must appraise the circumstances as the reasonable sober person would).

${ }^{21}$ See, e.g., Commonwealth v. Sheehan, 5 Mass. App. Ct. 754, 761, 370 N.E.2d 1021, 1025 26 (1977) (evidence of voluntary intoxication, as defined supra note 19, is irrelevant except to disprove premeditation in homicide), aff $d$ on other grounds, 376 Mass. 765, 771, 383 N.E.2d 1115, 1119 (1978). For other jurisdictions that deny evidence of intoxication in a failure of proof defense, see 2 P. Robinson, Criminal Law Defenses, supra note 18, \& 65 n.13.

${ }^{22}$ The rationales for strict liability do not apply here. Strict liability is frequently employed to avoid problems of proof and to deter harms caused in the course of certain highlydangerous activities. See generally Robinson, Imputed Criminal Liability, 93 Yale L.J. 609, 669-71 (1984) (discussing rationales for strict liability) (hereinafter cited as Robinson, Imputed Criminal Liability]. Clearly, the deterrence rationale does not apply to the wide variety of activities that may "proyoke" an attack necessitating self-defense. Nor does that rationale apply to all conduct that may create the conditions of an excuse, for example, drinking what one believes is nothing more than water. The problems-of-proof argument is similarly unpersuasive here. See infra section III(C).

${ }^{23}$ For cases that deny a self-defense justification upon a showing of any fault, see United States y. Peterson, 483 F.2d 1222, 1231 (D.C. Cir.), cert. denied, 414 U.S. 1007 (1973); Collier v. State, 57 Ala. App. 375, 328 So. $2 d 626$ (Crim. App. 1975), cert. denied, 295 Ala. 397, 328 So. $2 d 629$ (1976); People v. Holt, 25 Cal. 2d 59, 65-67, 153 P.2d 21, 25-26 (1944); Lindley v. State, 268 Ind. $83,88,373$ N.E.2d 886, 889 (1978); State v. Melchior, 56 Ohio St. 2d 15, 20-21, 381 N.E.2d 195, 199 (1978); Yarborough v. Commonwealth, 217 Va. 971, 975, 234 S.E.2d 286, 290 (1977). Wisconsin limits the availability of self-defense if the actor engaged in unlawful conduct that was "likely to provoke others to attack him." Wis. Stat. Ann. \& $938.48(2)$ (a) (West 1982). 
this approach avoids the improper presumption that every initial aggressor, even a justified one, ${ }^{24}$ is to blame for the resulting harm. A difficulty remains, however, in that although the actor's initial conduct may justify some responsive force, the force returned may be unnecessary or disproportionate. Consider the case of the unjustified attacker who breaks off his attack but is nonetheless pursued unnecessarily and the case of the passenger whose push to get on the bus is met with an excessive response. In both cases the initial aggressor may have been initially at fault, but denying a right of self-defense seems inappropriately harsh. ${ }^{28}$

A greater difficulty, present in all provisions that bar a justification defense based on the actor's fault in creating the justifying circumstances, ${ }^{28}$ is that it is unclear what it means to be "at fault" in causing the justifying circumstances. The process of creating a threat that requires some justified response involves a series of events. The actor must engage in some conduct, which then produces a condition that constitutes a threat, which then requires a justified response. With respect to which element(s) must the actor be at least negligent to be disqualified from a justification? In the firebreak case, for example, does one ask whether the actor was negligent as to having a defective muffler or as to whether the muffler would throw off a spark or as to whether it would throw off a spark and start a forest fire or as to whether it would throw off a spark and start a fire that would threaten a town or as to whether it would throw off a spark and start a fire that would threaten a town under conditions that would then justify his setting fire to the field? ${ }^{27}$

${ }^{24}$ Often in the case of public authority justifications, the justified actor is the initial aggressor. See Robinson, A Systematic Analysis, supra note 3, at 215-16 (1982).

${ }^{25}$ For statutes that allow the initial aggressor to regain the right of self-defense upon proper withdrawal, see supra notes 13,16 .

${ }^{26}$ This problem similarly arises with the Model Penal Code's choice of evils justification. See infra text accompanying notes 52-53.

${ }^{27}$ For statutes barring the lesser evils justification unless the situation giving rise to the defense arose through no fault, or without blame, of the actor, see Del. Code Ann. tit. 11, $\S 463$ (1979) (through no fault); Guam Crim. \& Corr. Code $\$ 7.80$ (1977) (through no fault); Ill. Ann. Stat. ch. 38, § 7.13 (Smith-Hurd 1972) (without blame); Mo. Rev. Stat. $\$ 563.026 .1$ (1978) (through no fault); N.Y. Penal Law $\$ 35.05(2)$ (McKinney 1975) (through no fault). Recognizing the failings of such "fault in causing the circumstances" statutes, Professor Fletcher would adopt "a sensible compromise" under which the actor would receive a justification defense (presumably even in the case of the "grand schemer," see infra section II(A)), 
Even if the focus of the fault inquiry were clear, there is a further, and greater, difficulty in an approach that excludes a defense because the actor was at fault in causing the defense: such an approach does not distinguish among different levels of fault in causing the conditions of the defense. ${ }^{28}$ The person who negligently starts the forest fire that justifies his later conduct receives the same treatment as the person who does so intentionally. For burning the firebreak, both would be convicted of the intentional offense of arson.

An actor who is culpable in causing the conditions of his excuse often receives analogous treatment. Several states, for example, deny an excuse defense to the actor who is unreasonably mistaken (negligent) in believing that he has a justification defense. ${ }^{2 \theta}$ Thus, the actor who irrationally and mistakenly believes that his friend is attacking him will lose his excuse of mistaken self-defense and will be convicted of murder (intentional killing). ${ }^{30}$

A murder conviction for such an actor seems improper, as he is certainly less blameworthy than the person who kills intentionally without even a claim of mistaken self-defense. Similarly, an actor who because of his intoxication is unable to "appreciate the wrongfulness" of his conduct or is unable to "conform his conduct to the requirements of the law" and commits a murder while in this disabled condition will lose his excuse if he was negligent as to becoming intoxicated. ${ }^{31}$ Although he may have intended to become

but would be obliged to pay civil compensation for any harm caused. G. Fletcher, Rethinking Criminal Law 798 (1978).

${ }^{28}$ For decisions that seem to require only a minimal level of culpability in bringing about the provocation to disqualify the defendant from a self-defense justification, see, e.g., Com.

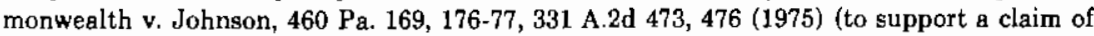
self-defense, a defendant must be free from fault in provoking or continuing the difficulty; the court did not consider the effect of the Pennsylvania statute cited infra note 34); State v. Woodham, 162 S.C. $492,502,160$ S.E. 885,889 (1931) (approving the following instruction to the jury: "self-defense is not available to a person who uses langunge so opprobrious as is reasonably calculated to bring on a difficulty and which really does contribute to a physical encounter").

28 See Alaska Stat. $\S \S 11.81 .330, .335$ (1983) (self-defense); Ariz. Rev. Stat. Ann. §§ 13404, to -405 (1978) (defense of others); N.J. Stat. Ann. § 2C:3-4(a) (West 1982) (defense of others). Note that these provisions codify an excuse defense in the definition of a justification. See Robinson, A Systematic Analysis, supra note 3, at 239-40.

${ }^{30}$ The actor, moreover, will not be eligible for a failure of proof defense, as he intends to cause his friend's death and thus satisfies the mental element for that offense.

"The excuse defense is completely unavailable if the actor "knowingly" introduced substances he either knew or "ought" to have known would tend to intoxicate him. Model Pe- 
intoxicated, he did not by his intoxication intend to kill. He was, at most, only negligent as to that result. ${ }^{32}$ Like the statutes on mistaken justification and on intoxication, many state provisions bar a duress excuse if the defendant was to some degree culpable as to putting himself in the coercive situation. ${ }^{33}$

nal Code $\S 2.08(4),(5)$ (b) (Proposed Official Draft 1962) (definition quoted infra text accompanying note 146). For further discussion of this point, see infra note 146 and accompanying text. Several states have adopted the above rule of $\$ 2.08$. See, e.g., Ala. Code § 13A-3-2 (1982); Ariz. Rev. Stat. Ann. \$\$ 13-105(33), -503 (Supp. 1984-1985); Ark. Stat. Ann. § 41-207 (1977); Colo. Rev. Stat. \$ 18-1-804 (1978); Del. Code Ann. tit. 11, $\$ 423$, 424(2) (1979); Guam Crim. \& Corr. Code $\$ 7.58(a)(2)$ (1977); Hawaii Rev. Stat. § $702-$ 230(3), (4)(b) (1976); Ky. Rev. Stat. $\$ \$ 501.010(4), .080(2)$ (1975); Me. Rev. Stat. Ann. tit. 17-A, § 37(2), (3)(B) (1983); N.J. Stat. Ann. § 2C:2-8(d), (e)(2) (West Supp. 1984-1985).

Similarly, Georgia defines as "involuntary" any intoxication that is produced by the coercion or trick of another or by "excusable ignorance." Ga. Code Ann. § 16-3-4(b) (1984), "Excusable ignorance" seems to imply faultlessness, and negligence will most likely be adequate to bar the actor's excuse. By contrast, South Dakota limits defense-denying "voluntary intoxication" to situations where the actor has knowingly introduced substances that tend to cause intoxication. S.D. Codified Laws Ann. § 22-1-2(49), -5-5 (1979 \& Supp. 1984). "Knowingly" apparently refers to both the introduction and the intoxicating quality of the substance.

${ }^{32}$ One can argue that a murder conviction is appropriate in both of these excuse cases because the actor satisfies the elements of the offense at the time of the homicide and is "at fault" as to causing his defense, but the argument is unpersuasive. Although at the time of the killing, the actor in the second example satisfies the elements of murder, his intoxication by that time renders him irresponsible and therefore not blameworthy for the murder. When the actor was responsible, prior to his intoxication, he did not satisfy the elements of murder.

ss For statutes completely denying a duress defense when the actor was culpable as to placing himself in the coercive situation, see Alaska Stat. $\S 11.81 .440$ (b) (1983) (duress defense barred if the actor recklessly entered a situation where he probably would be subject to coercion); Am. Samoa Code Ann. § 46.3213(b)(2) (1981) (same); Ariz. Rev. Stat. Ann. $\S 13-412(B)$ (1978) (barred if intentionally, knowingly, or recklessly entered a situation of probable coercion); Ark. Stat. Ann. $\$ 41-208$ (2) (1977) (barred if recklessly entered a situation of reasonably forseeable coercion); Colo. Rev. Stat. $\$ 18-1-708$ (1978) (barred if recklessly entered a situation of reasonably foreseeable coercion); Conn. Gen. Stat. Ann. $\S 53 a-$ 14 (West 1972) (barred if intentionally or recklessly entered a situation of probable coercion); Del. Code Ann. tit. 11, § 431 (1979) (same); Guam Crim. \& Corr. Code § 7.61(b) (1977) (intentionally, knowingly, or recklessly); Ind. Code Ann. $\$ 35-41-3-8(b)(1)$ (Burns 1979) (intentionally, knowingly, or recklessly entered a situation of foreseeable coercion); Kan. Stat. Ann. \$ 21-3209(2) (1981) (willfully or wantonly entered a situation of probable coercion); Ky. Rev. Stat. \& 501.090(2) (1975) (intentionally or wantonly entered a situation of probable coercion); Mo. Rev. Stat. $\S 562.071 .2$ (1978) (recklessly entered a situation of probable coercion); N.Y. Penal Law $\$ 40.00$ (2) (McKinney 1975) (intentionally or recklessly entered a situation of probable coercion); Or. Rev. Stat. $\$ 161.270(2)$ (1983) (same); Tex. Penal Code Ann, § 8.05(d) (Vernon 1974) (intentionally, knowingly, or recklessly entered a situation of probable coercion); Utah Code Ann. § 76-2-302(2) (1978) (same); Wash. Rev. Code Ann. \$ 9A.16.060(3) (1977) (intentionally or recklessly entered a situation of probable coercion). 
Some statutes resolve a few of the problems raised by the "at fault" approach. Their provisions establish that the relevant question is whether the actor was at fault as to creating the defense conditions in order to commit an offense. For example, many jurisdictions bar self-defense where the actor "provokes the use of force against himself with the intent to use such force as an excuse to inflict bodily harm upon the assailant . . . ."34 Thus, in contrast to the result under the provision noted above, it is not enough for the state to show that the actor was culpable as to creating the conditions of his defense. Rather, the actor must have been culpable as to committing the offense at the time he created the conditions of his defense. ${ }^{36}$ Further, by requiring a high level of culpability as to an ultimate offense, ${ }^{36}$ these provisions avoid convicting an actor of an intentional offense when the actor was only reckless or negligent as to its eventual commission.

Even these statutes are not ideal. ${ }^{37}$ First, under most of them,

34 Ga. Code Ann. $\$ 16-3-21(b)(1)$ (1984). For statutes in substantial accord, see Ala. Code $\S 13 A-3-23(c)(1)$ (1982); Alaska Stat. $\$ 11.81 .330(a)(2)$ (1983); Ark. Stat. Ann. $\$ 41-$ 506(2)(a) (1977); Colo. Rev. Stat. \& 18-1-704(3)(a) (Supp. 1984); Conn. Gen. Stat. Ann. § 53a-19(c)(1) (West 1972); Ill. Ann. Stat. ch. 38, § 7-4(b) (Smith-Hurd 1972); Ind. Code Ann. § 35-41-3-2(d)(2) (Burns Supp. 1984); Iowa Code Ann. § 704.6(2) (West 1979); Kan. Stat. Ann. § 21-3214(2) (1981); Ky. Rev. Stat. § 503.060(2) (1975); Me. Rev. Stat. Ann. tit. 17-A, $\S 108(1)(A),(2)(C)(1)(1983)$; N.H. Rev. Stat. Ann. $\S 627: 4(I)(a)$, III(c) (1974); N.Y. Penal Law \$ 35.15(1)(a) (McKinney 1975); N.D. Cent. Code $\$ 12.1-05-03(2)$ (a) (1976); Or. Rev. Stat. § 161.215(1) (1983); Utah Code Ann. \$ 76-2-402(2)(a) (1978); Wis. Stat. Ann. $\S 939.48(2)$ (c) (West 1982); cf. Mont. Code Ann. $\$ 45-3-105$ (2) (1983) (self-defense not available to one who purposely or knowingly provokes the use of force against himself).

A few provisions bar only the use of deadly force to one who provokes the use of force against himself for the purpose of causing serious harm or death. See Del. Code Ann. tit. 11, $\S 464(\mathrm{e})(1)(1979)$; Guam Crim. \& Corr. Code $§ 7.86(\mathrm{~b})(1)$ (1977); Hawaii Rev. Stat. § 703304(5)(a) (1976); Neb. Rev. Stat. § 28-1409(4)(a) (1979); N.J. Stat. Ann. § 2C:3-4(b)(2)(a) (West 1982); $18 \mathrm{~Pa}$. Cons. Stat. Ann. $\S 505$ (b)(2)(i) (Purdon 1983); Model Penal Code $\S 3.04(2)$ (b)(i) (Proposed Official Draft 1962).

${ }^{36}$ The Montana statute seems to require culpability only as to provoking an attack and not as to an ultimate offense. Mont. Code Ann. § 45-3-105(2) (1983).

38 The Montana statute requires less culpability, either purpose or knowledge as to provoking the attack against oneself. Mont. Code Ann. $\$ 45-3-105(2)$ (1983).

"The "intentional provocation" provisions are usually coupled with "initial aggressor" or "initial provoker" provisions that seem to deny the defense with no inquiry into fault. See the statutes cited supra notes 13,16,34. Only in Alaska may one who provokes the attack with the intent of causing injury regain the defense of self-defense by withdrawing. See Alaska Stat. $\$ \S 11.81 .330, .335$ (1983). In the other jurisdictions, discussed in the cited notes, the initial aggressor and the mere provoker may regain the defense, but the intentional provoker cannot. That an "aggressor" did not intend to provoke an attack that would 
the actor will lose a self-defense claim to a charge of murder even when he intends only to provoke the conditions for a defense to a charge of assault or of causing bodily harm. ${ }^{3 \mathrm{~g}}$ Thus, he will lose any justification defense and be liable for murder if his intentional verbal harassment is met with deadly force rather than the fist fight that he anticipates. ${ }^{3 \theta}$ Second, the provisions may be too liberal in some cases. If an actor is reckless as to provoking an attack that will require him to respond with deadly force, he will retain his right of self-defense. If an actor who intentionally creates a justification to kill can be convicted of intentional homicide, however, why then should the actor who is reckless as to creating such a situation not be convicted of reckless homicide? ${ }^{40}$

The "at fault" provisions, even at best, are defective because they are oversimplified. Although apparently based on principles of fault and blameworthiness, these provisions actually avoid the relevant inquiry - the actor's culpability as to committing the offense-and instead rely on rough-and-ready rules that only roughly approximate the results dictated by the culpability principle.

justify a response may thus matter only in that he, but not the intentional provoker, may regain his defense if he withdraws.

${ }^{38}$ A few of the statutes require culpability as to a more serious offense. See Ky. Rev. Stat. $\S 503.060(2)$ (1975) (defense barred if actor had intention of causing death or serious physical injury); N.D. Cent. Code $\$ 12.1-05-03,-07$ (1976) (barred if actor had intention of caus. ing bodily injury or death); Wis. Stat. Ann. $\$ 939.48(2)$ (c) (West 1982) (death or great bodily harm). The Kentucky and Wisconsin provisions, however, have another undesirable effect. They permit a defense for the person who intends to provoke an attack that will allow him to inflict an injury that does not rise to the level of "serious" or "great." Thus, he can escape liability for the exact offense that he intended to commit.

${ }^{30}$ Even if the actor withdraws when he meets with deadly force, he will not be able to regain the right of self-defense. See supra note 16.

"One jurisdiction attempts to deal with this issue. In Wisconsin, "[a] person who engages in unlawful conduct of a type likely to provoke others to attack him and thereby does provoke an attack is not entitled to claim the privilege of self-defense against such attack ... . Wis. Stat. Ann. $\S 939.48(2)$ (a) (West 1982). This provision is flawed, however, in a way similar to the Model Penal Code intoxication provision discussed supra text accompanying note 31 . It permits conviction for intentional homicide if the actor merely engaged in conduct "likely to provoke" an attack. As the statute does not seem to require the defendant's awareness of the likelihood of provocation, it seems to bar a defense, even to intentional homicide, if the actor was merely negligent as to the provocative nature of his conduct. 


\section{Imposing Reduced Liability upon a Minimum Culpability as to Causing the Defense Conditions}

A common alternative to barring a defense altogether if the actor is at fault in causing the conditions of his defense is to bar a complete defense but to permit a mitigation of liability. This approach is reflected in one form of the doctrine of "imperfect self-defense." This doctrine applies where an actor provokes a battle but then justifiably kills to defend himself. In this situation, he will be denied total or "perfect" exoneration but will qualify for a mitigation in liability from murder to voluntary manslaughter." This approach is based on the view that an actor who is partially "at fault" in causing the conditions of his defense is more culpable than an actor who is entirely free from fault, but is less culpable than an actor who does not satisfy the defense conditions.

One problem with this version of "imperfect self-defense" is that it is unclear why mitigation is appropriate only in homicide offenses and only for the self-defense justification. ${ }^{42}$ An even more important problem with this approach is that it fails to account for different degrees of culpability in causing the conditions of a defense. The initial aggressor who is only negligent as to causing the justifying circumstances receives the same treatment as the initial aggressor who is reckless. ${ }^{43}$ The actor who is negligent as to becoming intoxicated is treated the same as the actor who becomes so intentionally. ${ }^{44}$

An analogous mitigation is used where voluntary intoxication is offered as a failure of proof defense. Most jurisdictions allow this

43 See, e.g., State v. Potter, 295 N.C. 126, 144, 244 S.E.2d 397, 409 (1978).

12 One jurisdiction does permit mitigation in all offenses where the actor culpably causes the conditions of a general intoxication excuse. See Tex. Penal Code Ann. $\$ 8.04$ (b) (Vernon 1974) (implying that evidence of temporary insanity caused by voluntary intoxication may be introduced in mitigation of penalty but not as a defense). This treatment permits conviction for an of fense requiring purpose, knowledge, or recklessness, allowing only mitigation in punishment, even where the actor is only negligent as to causing the conditions of his defense, becoming intoxicated. In Hanks v. State, 542 S.W.2d 413 (Tex. Crim. App. 1976), the defendant was aware that a "suspected" drug was placed in his drink, but the court did not evaluate whether he was aware of the type of drug or the effect that the drug might have. The court nevertheless, consistent with the Texas position on intoxication, denied a defense to murder.

43 See State y. Potter, 295 N.C. 126, 144 n.2, 244 S.E.2d 397, 409, n.2 (1978) (proposition implied).

"See Tex. Penal Code Ann. \$ 8.04(b) (Vernon 1974). 
defense for offenses requiring purpose or knowledge but deny it for other, lesser-included offenses. ${ }^{45}$ Thus, a voluntarily intoxicated killer is not punished as a murderer, but neither is he given a complete defense, even if he has no culpability as to causing death. Recklessness will be imputed to him and will provide the basis for a manslaughter (reckless homicide) conviction. The most common rationale given for this rule is that the actor's culpability in becoming intoxicated is an adequate basis on which to impute recklessness as to committing the offense. ${ }^{46}$

Denying a failure of proof defense for voluntary intoxication that negates the recklessness required for manslaughter is troubling,

40 The Model Penal Code, for example, holds an actor liable by treating him as if he were aware of a risk, even though he is unaware of it, if his unawareness is due to self-induced intoxication. Model Penal Code $\$ 2.08$ (2) (Proposed Official Draft 1962) ("When recklessness establishes an element of the offense, if the actor, due to self-induced intoxication, is unaware of a risk of which he would have been aware had he been sober, such unawareness is immaterial."). For a comprehensive list of jurisdictions adopting this position, see $1 \mathrm{P}$. Robinson, Criminal Law Defenses, supra note 18 , $\$ 65$ n.6.

Oregon law provides the following:

(1) The use of drugs or controlled substances, dependence on drugs or controlled substances or voluntary intoxication shall not, as such, constitute a defense to a criminal charge, but in any prosecution for an offense, evidence that the defendant used drugs or controlled substances, or was dependent on drugs or controlled substances, or was intoxicated may be offered by the defendant whenever it is relevant to negative an element of the crime charged.

(2) When recklessness establishes an element of the offense, if the defendant, due to the use of drugs or controlled substances, dependence on drugs or controlled substances or voluntary intoxication, is unaware of a risk of which the defendant would have been aware had the defendant been not intoxicated, nat using drugs or controlled substances, or not dependent on drugs or controlled substances, such unawareness is immaterial.

Or. Rev. Stat. $\$ 161.125$ (1983); accord Ala. Code § 13A-3-2(a), (b) (1982); Am. Samoa Code $\S 46.3214$ (1981); Conn. Gen. Stat. Ann. $\$ 53 \mathrm{a}-7$ (West 1972); Me. Rev. Stat. Ann. tit. 17-A, $\S 37$ (1983); N.J. Stat. Ann. $\$ 2$ C:2-8(a), (b) (West Supp. 1984-1985); N.Y. Penal Law $\S \S 15.05(3), 15.25$ (McKinney 1975); N.D. Cent. Code $\S 12.1-04-02$ (Supp. 1983).

Other jurisdictions limit the defense more severely. A few bar evidence of voluntary intoxication regardless of the offense. See 2 P. Robinson, Criminal Law Defenses, supra note 18, $\S 65 \mathrm{n} .13$. Others permit voluntary intoxication evidence only where it is relevant to negate a "specific intent." See id. $\$ 65$ n.11. Others permit the evidence where it is relevant to negate purpose, motive, or intention. See id. $\$ 65$ n. 10 .

${ }^{46}$ See People v. Walker, 58 A.D.2d 737, 396 N.Y.S.2d 121 (1977) (even if defendant's voluntary intoxication was a factor in his shooting of the victim after an argument, such intoxication constituted reckless conduct that amounted to manslaughter); see also Model Penal Code $\S 2.08$ comment 3, at 8-9 (Tent. Draft No. 9, 1959) ("we believe it fair to postulate a general equivalence between the risks created by the conduct of the drunken actor and the risks created by his conduct in becoming drunk"). 
however, for a number of reasons. The problems are analogous to those that arise from rejecting a general intoxication excuse when the intoxication is voluntary. First, the imputation of culpability--recklessness under codes following the Model Penal Code, and greater culpability under many other codes-is generally triggered by a definition of "voluntariness" in becoming intoxicated that requires only negligence. Intoxication is "self-induced" under the Model Penal Code, for example, if the actor "knows or ought to know" the tendency of the substance to intoxicate. ${ }^{17}$ Assume that $X$ kills a pedestrian by driving at a speed that he should know risks such a death, but that he does not know of the risk because of his voluntary intoxication. The Model Penal Code would convict him of reckless homicide, despite his unawareness of the risk. His conviction would stand even if he had only been negligent in becoming intoxicated. Thus, he could be found guilty of reckless homicide if a neighbor gave him what he honestly but erroneously believed to be a regular cigarette if he should have known (perhaps because it was hand-rolled) that it might contain an intoxicating substance. $^{48}$

Second, the imputation of recklessness is objectionable because even if the actor is reckless, or even purposeful, as to getting intoxicated, it does not follow that he is reckless as to causing the death of the pedestrian. The notion that a person risks all manner of resulting harm when he voluntarily becomes intoxicated is common, ${ }^{49}$ but is obviously incorrect. ${ }^{50}$

17 Model Penal Code $\$ 2.08$ (5)(b) (Proposed Official Draft 1962) (enìphasis added).

${ }^{48}$ The Model Penal Code definition of "self-induced intoxication" has an additional flaw: it does not take account of situations in which an actor may know of the intoxicating effect caused by his drinking, but is not fully responsible for that drinking, as in the case of the chronic alcoholic. See infra section $\operatorname{II}(\mathrm{F})(2)$.

${ }^{49}$ Indeed, the Model Penal Code drafters supported their presumption of recklessness by stating that the "awareness of the potential consequences of excessive drinking on the capacity . . . to gauge the risks incident to . . . conduct" is sufficiently widespread to justify an equation of the actor's culpability in becoming intoxicated with the actor's culpability in committing an offense requiring recklessness. Model Penal Code $\$ 2.08$ comment 3 , at 9 (Tent. Draft No. 9, 1959); see Lloyd v. State, 42 Md. App. 167, 170, 399 A.2d 932, 934-35 (1979) ("extreme" intoxication by itself may indicate a wanton and reckless disregard for human life and therefore may support a finding of gross negligence sufficient for a manslaughter conviction).

so Hawaji rejects the Model Penal Code provision for just this reason: "It equates the defendant's becoming drunk with the reckless disregard by him of risks created by his subsequent conduct and thereby forecloses the issue." Hawaii Rev. Stat. $\$ 702-230$ commentary 
Finally, the imputation of a culpable state of mind when none truly exists seems particularly strange for the Model Penal Code drafters. These drafters actively opposed placing the burden of persuasion on the defendant for most defenses. Yet as to intoxication, the drafters permit what is in essence an irrebuttable presumption as to the existence of an element of the offense. ${ }^{51}$

\section{Imposing a Degree of Liability Corresponding to the Level of Culpability as to Causing the Defense Conditions}

In a few provisions, the Model Penal Code demonstrates greater sensitivity to differences in culpability as to causing the conditions of one's defense. Its choice-of-evils justification, for example, provides that "when the actor was reckless or negligent in bringing about the situation requiring a choice of harms or evils ... the [choice of evils] justification . . . is unavailable in a prosecution for any offense for which recklessness or negligence, as the case may be, suffices to establish culpability." 52 The Commentary explains that the drafters chose this approach because it "precludes convic-

(1976); see also Model Penal Code § 2.08 comment 3, at 7 (Tent. Draft No. 9, 1959) (reporting that Judge Hand and other members of the Advisory Committee preferred a rule that would permit voluntary intoxication to negate recklessness).

"I Indeed, it can be argued that such a presumption of recklessness would be unconstitutional under Mullaney v. Wilbur, 421 U.S. 684 (1975), and Patterson v. New York, 432 U.S. 197 (1977). Under Mullaney and Patterson, the burden of disproving an essential element of the offense cannot be allocated to the defendant. Patterson, 432 U.S. at 210, 215-16; Mullaney, 421 U.S. at 701-02. Moreover, mandatory presumptions are allowed only where they are rebuttable, Sandstrom v. Montana, 442 U.S. 510, 523 (1979), and where they are triggered by evidence that "is sufficient to support the inference of guilt beyond a reasonable doubt." County Court v. Allen, 442 U.S. 140, 166 (1979).

It is possible, however, that the rules governing voluntary intoxication need not be analogized to irrebutable evidentiary presumptions. They may instead rely upon notions of equivalent culpability rather than a theory of evidentiary presumptions. In other words, it may be not that recklessness is presumed, but that the actor who is voluntarily intoxicated is considered as culpable as one who is reckless. See generally Robinson, Imputed Criminal Liability, supra note 22, at 660-63 (discussing rationales for punishing the voluntarily intoxicated). For a discussion of limitations on theoretical solutions to culpability in causing dictated by Supreme Court decisions, see infra section III(D).

52 Model Penal Code $\$ 3.02(2)$ (Proposed Official Draft 1962); accord Am. Samoa Code Ann. § 46.3304(b) (1981); Ark. Stat. Ann. § 41-504(3) (1977) (using Model Penal Code formulation); Hawaii Rev. Stat. § 703-302(2) (1976) (using Model Penal Code forumulation); Ky. Rev. Stat. $\S 503.030(2)$ (1975) (requiring wantonness or recklessness, whereas $\S 3.02$ requires negligence or recklessness); Me. Rev. Stat. Ann. tit. 17-A, $\$ 103(2)$ (1983) (using Model Penal Code formulation, but substitutes criminal negligence where the Code uses negligence); Neb. Rev. Stat. $\$ 28-1407(2)$ (1979) (using Model Penal Code formulation); 
tion of a purposeful offense when the actor's culpability inheres in recklessness or negligence, while sanctioning conviction for a crime for which that kind of culpability is otherwise sufficient to convict." 53 This approach raises several questions, however.

First, we have already seen the ambiguity in a requirement that an actor be culpable as to "causing" the conditions of his defense. The Model Penal Code Commentary's reference to instances when "the actor's culpability inheres in recklessness or negligence"ss is no improvement. To which events in the chain of events creating the conditions of the defense must that culpability apply: recklessness as to having a defective muffler, or as to having a muffler that will start a forest fire that will then threaten a town and thereby create the need for justified conduct?

Second, the provision inexplicably fails to treat the case where an actor purposely or knowingly creates the triggering conditions. The anomaly is compounded because the failure to include such a case in a provision limiting the defense suggests that the purposeful or knowing actor retains the defense. Thus, one who intentionally sets the forest fire would receive the defense, whereas the defendant who only negligently creates the conditions that trigger the defense would not. ${ }^{\mathrm{s}}$

N.H. Rev. Stat. Ann. § 627:3(II) (1974) (same); 18 Pa. Cons. Stat. Ann. § 503(b) (Purdon 1983) (same).

s3 Model Penal Code $\S 3.02$ comment 1, at 6 (Tent. Draft No. 8, 1958).

s4 See supra text accompanying notes 26-27.

os This anomaly may be an inadvertent result of a paramount concern with avoiding excessive liability for an actor whose culpability is relatively minor. See supra notes 26-27 and accompanying text. One might argue that a defendant who is purposeful or knowing "in bringing about the situation" may be held liable for a reckless or negligent offense. A general provision of the Code, $\S 2.02(5)$, provides that when negligence suffices to establish an element of the offense, it is also satisfied if the actor is purposeful, knowing, or reckless with respect to that element. ModeI Penal Code $\$ 2.02(5)$ (Proposed Official Draft 1962). The use of two culpability terms, "reckless" and "negligent," in $\S 3.02(2)$ suggests, however, that the drafters did not intend $\S 2.02(5)$ to apply; if that had been their intent, use of the term "negligence" would have sufficed. Simple rules of statutory construction lead to the conclusion that by identifying two culpable states, the drafters intended to exclude the others. Model Penal Code $\S 3.04(2)(\mathrm{b})(\mathrm{i})$ lends further credence to this interpretation. In $\$ 3.04(2)(b)(i)$, the drafters specifically address the case of the defendant who purposely creates the justifying circumstance for self-defense and do not address the actor who is reckless or negligent as to provoking the use of force against himself. It seems, then, that the drafters intended to treat only the reckless or negligent actor in lesser evils, and only the purposeful one in self-defense.

${ }^{36}$ Model Penal Code $\S 3.02$ comment 1, at 6 (Tent. Draft No. 8, 1958). 
Finally, the provision assumes a structure of offense culpability that is inconsistent with the offense-defining provisions of the Code. If an actor is reckless or negligent in causing the justifying circumstances, the Code bars the defense for "any offense for which recklessness or negligence, as the case may be, suffices to establish culpability." ${ }^{57}$ Nowhere is such a "reckless offense" or "negligent offense" concept defined or explained. It appears to presume a culpability system in which every offense has a single culpability requirement. This presumption is most unusual, coming as it does from draftsmen who were pioneers in providing the theoretical insight that offenses do not have one required level of culpability, but rather may have a different culpability requirement as to each objective element of an offense. ${ }^{58}$ To speak of the actor's culpability as somehow "inher[ing] in recklessness or negligence," as the Code Commentary tries to explain it, ${ }^{38}$ is to reject the systematic "element analysis" approach carefully laid down by the Code in $\S 2.02$ and to regress to the vague and mystical "offense analysis" view of culpability requirements. ${ }^{60}$

The Code sometimes uses a similar approach when an actor causes the conditions of an excuse. $\mathrm{He}$ is liable for an offense having the level of culpability that he possessed with respect to causing his disability or excusing conditions. Thus, under the Code, an actor who is only negligent in being placed under duress could be convicted only of a negligent offense. The Code, however, then reverts to a pure "at fault" approach when the actor is at least reckless as to being placed under duress. The reckless actor will lose the defense completely. ${ }^{61}$ The Code is therefore only partially suc-

${ }^{57}$ Id. $\$ 3.02(2)$ (Proposed Official Draft 1962).

sa See generally Robinson \& Grall, Element Analysis, supra note 8, at 694-99 (explaining the Model Penal Code's method of requiring a specific culpability for each offense element).

so See Model Penal Code $\S 3.02$ comment 1, at 6 (Tent. Draft No. 8, 1958).

Bo Cf. Robinson \& Grall, Element Analysis, supra note 8, at 715-19 (distinguishing element analysis from offense analysis and discussing the use of both forms of analysis in the Model Penal Code).

${ }^{61}$ Model Penal Code $\S 2.09$ (2) (Proposed Official Draft 1962); accord Ala. Code $§ 13 \mathrm{~A}-3$. 30(b) (1982) (defense unavailable if actor intentionally or recklessly places himself in situation; if negligently, defense unavailable for negligent offense); Hawaii Rev. Stat. $\S 702-$ 231(2) (1976) (Model Penal Code formulation); Me. Rev. Stat. Ann. tit. 17-A, § 103A(3)(B) (1983) (Model Penal Code formulation); N.J. Stat. Ann. \$2C:2-9(b) (West 1982) (Model Penal Code formulation, except that "criminal negligence" is substituted for the word "negligence," and a special provision is made for murder); $18 \mathrm{~Pa}$. Cons. Stat. Ann. $\S 309$ (b) (Purdon 1983) (Model Penal Code formulation); cf. N.D. Cent. Code $\$ 12.01-05-10(2)$ (1976) 
cessful in accounting for different levels of culpability in causing the conditions of the excuse. Where $A$ intentionally wounds $B$ while in a state of coercion that would normally provide a duress excuse, $A$ would nonetheless be convicted of intentionally wounding $B$, so long as $A$ was even reckless as to placing himself in a situation where coercion was likely.

Even if the actor's liability were limited to the degree commensurate with his level of culpability as to causing the conditions of his excuse, however, the statute would suffer the same shortcomings displayed in the context of lesser evils. One who is reckless as to placing himself in a situation where he will be subjected to coercion is not necessarily reckless as to being coerced into injuring another. ${ }^{82}$ Similarly, although an actor may intentionally place himself in a coercive situation to help a relative held hostage, he does not necessarily intend to be coerced to commit a robbery. To bar a duress defense in such a case simply does not generate liability proportionate to the actor's culpability.

\section{E. Inconsistent Approaches Within the Same Jurisdiction}

A survey of five defenses--self-defense, lesser evils, the intoxication excuse, duress, and intoxication as a failure of proof defense-reveals that the Model Penal Code treats the issue of causing the conditions of one's defense differently in each of the five instances. The Model Penal Code denies a defense on a showing of a minimum level of culpability for three defenses-the intoxication excuse, the duress defense where the actor is reckless in placing himself in the coercive situation, and the self-defense justification. ${ }^{63}$ For the defense of intoxication negating an element, the

(pure "at fault" approach applies only when actor willfully enters a duress situation by voluntarily entering into a "criminal enterprise"). The duress statutes cited supra note 33 codify the Model Penal Code's complete bar to the defense where recklessness is at issue, but do not provide a special negligence provision.

${ }^{\text {A2 }}$ The Missouri duress statute arguably corrects this problem by barring the defense only where the actor "recklessly places himself in a situation in which it is probable that he will be subjected to the force or threatened force." Mo. Rev. Stat. § 562.071.2(2) (1978). One can construe this provision to bar a defense only to the actor who risked being coerced to commit the offense that he committed. The Missouri statute is listed supra note 33 because it makes no adjustment in levels of liability for varying levels of culpability in causing one's defense.

*3 Model Penal Code $\$ 2.08(4)$, (5)(b) (Proposed Ofricial Draft 1962) (intoxication excuse denied if actor is negligent as to intoxication); id. $\$ 2.09(2)$ (duress excuse denied if actor is 
Code imposes a reduced degree of liability on a showing of a minimum lcvel of culpability as to causing the defense conditions. ${ }^{64}$ In two other defenses-lesser evils ${ }^{65}$ and duress where the actor is negligent in placing himself in the coercive situation ${ }^{66} \ldots$ the Code imposes a degree of liability that corresponds to the actor's level of culpability in causing the conditions of his defense. ${ }^{67}$

Further variations exist. In four of the defenses, the relevant issue is the actor's culpability as to causing the conditions of his defense. $^{88}$ In only one case does the actor's liability depend on his culpability as to the ultimate offense. ${ }^{60}$

The defenses, moreover, differ as to the degree of culpability that will disable an actor from successfully invoking the defense. In four of these defenses, if the actor is negligent he either loses the defense entirely or at least loses the opportunity for a complete defense. ${ }^{70}$ In the fifth defense the critical culpability level--that level at which he will lose the defense-is much higher; purpose is required. ${ }^{71}$

Thus, within this one code actors who cause the conditions of a defense are treated in very different ways depending on the defense, even where similar defenses are at issue. The Code treats the two justification defenses differently in three respects ${ }^{72}$ and treats

reckless as to being subjected to coercion); id. $\S 3.04(2)$ (b)(i) (self-defense justification denied if actor intended to provoke an attack that would justify his use of deadly force in response). This approach is discussed supra section $\mathrm{I}(\mathrm{B})$.

44 Model Penal Code $\$ 2.08$ (Proposed Official Draft 1962) (if actor is negligent as to intoxication, his intoxication can negate negligence, purpose, or knowledge, but recklessness is always imputed). This approach is discussed supra section $\mathrm{I}(\mathrm{C})$.

or Model Penal Code $\$ 3.02(2)$ (Proposed Official Draft 1962).

${ }^{86}$ Id. § 2.09(2).

${ }^{67}$ This approach is discussed supra section I(D).

${ }^{68}$ See Model Penal Code $\S 2.08(2)$ (Proposed Official Draft 1962) (intoxication negating an element); id. $\$ 2.08(5)$ (b) (intoxication as a general excuse); id. $\$ 2.09$ (2) (duress); id. $\S 3.02(2)$ (lesser evils).

${ }^{\theta}$ Id. $\S 3.04(2)$ (b)(i) (use of deadly force in self-defense).

${ }^{20}$ Id. $\$ 2.08(4),(5)(b)$ (intoxication as a general excuse; loses defense entirely); id. $\S 2.08(1),(2),(5)$ (b) (intoxication negating an element; actor does not lose defense entirely but instead obtains a reduction in liability to an offense that requires recklessness); id. $\S 2.09$ (2) (duress; if actor is negligent, he can be convicted only of an offense of negligence or strict liability; recklessness bars the defense entirely); id, $\S 3.02$ (2) (lesser evils; if actor is negligent he can be convicted only of an offense of negligence or lesser culpability; if reckless, then can be convicted only of an offense requiring recklessness or lesser culpability).

$"$ Id. ₹ 3.04(2)(b)(i) (self-defense).

${ }^{72}$ Compare id. $\$ 3.02(2)$ (lesser evils) with id. $\S 3.04(2)$ (b)(i) (self-defense). In lesser evils, negligence is sufficient to deny the defense in some cases; in self-defense, only purpose will 
the excuse defenses in three different ways. ${ }^{73}$ A particular excuse defense, duress, is itself treated in two ways. ${ }^{74}$ Intoxication negating an offense element is given a unique treatment. ${ }^{70}$

Several jurisdictions have adopted these inconsistencies. ${ }^{78}$ Other jurisdictions add their own inconsistencies by further refining the self-defense situation. An initial "aggressor" will lose the defense even if he was not culpable as to causing either the defense or the ultimate harm, but one who simply "provokes" an attack must do so with an intent to gain a defense before he will lose the defense. ${ }^{77}$ At least one jurisdiction adds another distinction by ignoring an actor's culpability in causing his defense where his intoxication negates an offense element. ${ }^{7}$ Other jurisdictions eliminate a Model Penal Code inconsistency by treating all cases of duress identi-

deny the defense. In lesser evils, a culpable actor loses the defense for offenses requiring equivalent or lesser culpability; in self-defense, the culpable actor loses the defense regardless of the offense charged. Finally, in lesser evils, the actor may be culpable only as to causing the conditions of the defense to lose the defense, but in self-defense, the actor must be culpable as to the ultimate offerse.

"s Compare id. $\S 2.08(4),(5)(b)$ (intoxication excuse) with id. $\S 2.09$ (2) (duress). In intoxication, negligence as to causing the defense conditions bars the excuse regardless of the offense, whereas in duress, only recklessness as to causing the defense conditions bars the excuse. In duress, negligence as to the defense conditions bars the defense only for an offense requiring negligence, whereas in the intoxication excuse, negligence results in a bar to the defense regardless of the offense. Finally, whereas instances of culpably causing an intoxication defense are treated identically-the defense is barred-instances of culpably causing a duress defense are treated differently. In some cases, the defense is barred entirely; in others the defense is barred only for particular offenses.

"Id. $\S 2.09(2)$ (recklessness bars defense; negligence permits conviction only for an offense of negligence or strict liability).

7t Id. $\S 2.08(1),(2),(5)$ (b) (voluntarily intoxicated actor cannot use intoxication to rebut recklessness as to the elements of an offense).

7s For inconsistent treatment of justifications, compare Hawaii Rev. Stat. $§ 703-302(2)$ (1976) (lesser evils) with id. $\S 703.304(5)$ (a) (self-defense).

For inconsistent treatment of intoxication defenses and of duress, compare Hawaii Rev. Stat. $\S 702-230(3),(4)$ (b) (1976) (intoxication excuse), with id. $\S 702-231$ (2) (duress). Also, compare N.J. Stat. Ann. \& 2C:2-8(a), (b), (d), (e)(2) (West Supp. 1984-1985) (intoxication excuse and failure of proof defense), with id. $\$ 2 \mathrm{C}: 2-9$ (b) (West 1982) (duress).

For intoxication negating an element, see Hawaii Rev. Stat. $\S 702-230(1)$ (1976) (intoxication negating an element is always a defense, thus adding another deviation).

${ }^{77}$ Compare statutes cited supra notes 11,16 with statutes cited supra notes $34-40$. A further type of distinction in this area is between initial provokers, or aggressors, who retain the defense if they withdraw, and intentional provokers, who usually lose the defense completely. See supra notes $13,16,37$.

7 See Hawaii Rev. Stat. $\S 702-230(1)$ (intoxication negating an element always a defense). 
cally. ${ }^{78}$ These jurisdictions, however, introduce a new inconsistency: negligence will cause the actor to lose an intoxication $\mathrm{ex}$ cuse, but recklessness is required for him to lose a duress excuse. ${ }^{80}$

\section{F. Failure to Consider an Actor's Culpability in Causing the Conditions of his Defense}

Perhaps worse than the inconsistent treatment of actors who cause the conditions of different defenses is the basic inconsistency, found in every jurisdiction, that arises when the law simply fails to account for some actors who cause the conditions of their defenses. Many states fail to consider an actor's causing his own defense in many instances where it may be relevant, such as causing a duress excuse, a lesser evils defense, a justification defense of special responsibility or of defense of property, ${ }^{\mathbf{1}}$ or an insanity defense. ${ }^{82}$ A notable example of this attitude is found in Fain $v$. Commonwealth, ${ }^{83}$ where the defendant offered an involuntary act defense by claiming that he had a sleep disorder that caused him to act violently on being awakened:

If the prisoner is and has been afflicted in the manner claimed, and knew, as he no doubt did, his propensity to do acts of violence when aroused from sleep, he was guilty of a grave breach of social duty in going to sleep in the public room of a hotel with a deadly weapon on his person, and merits, for that reckless disregard of the safety of others, some degree of punishment, but we know of no law under which he can be punished. Our law only punishes for overt acts done by responsible moral agents. If the prisoner was unconscious when he killed the deceased, he cannot be punished for that act, and as the mere fact that he had the weapon on his person and went to sleep with it there did no injury to any one, he

78 See duress statutes cited supra note 33 .

so For example, compare Ark. Stat. Ann. $\S 41-208(2)$ (1977) (duress) with id. § 41-207(1), (2)(b) (intoxication excuse).

${ }^{81}$ See, e.g., Model Penal Code $\S 3.06$ (Proposed Official Draft 1962) (protection of property); id. $\S 3.08$ (special responsibility). Compare id. $\S 3.04(b)(1)$ (purpose to invoke the defense bars the use of deadly force in self defense) with id. $\S 3.06$ (d) (a defense of property provision that is a parallel to the deadly force provision in self-defense, but lacks any consideration of the actor's culpability as to causing the defense conditions).

82 See State v. Maik, 60 N.J. 203, 215-16, 287 A.2d 715, 721-22 (1972) (where insanity is at issue, court will not consider the etiology of the disease).

83 $78 \mathrm{Ky} .183$ (1879). 
cannol be punished for that. ${ }^{84}$

Yet every jurisdiction considers an actor's causing his own defense for some defenses, and every jurisdiction thus acknowledges that such causing-one's-defense can be relevant to an actor's liability. If it is relevant when an actor causes one defense, why is it not equally relevant when he causes another?

One might argue that the issue of causing-one's-defense does not arise in most defenses. This argument is undercut, however, by the existence of statutory provisions that consider it to some degree for a wide variety of defenses. At least two jurisdictions consider it in the context of insanity; ${ }^{85}$ another considers it for hypnosis. ${ }^{86}$ Many jurisdictions consider the issue for duress; ${ }^{87}$ several consider it for lesser evils. ${ }^{88}$ Many consider it for self-defense, ${ }^{88}$ many for defense of others, ${ }^{90} \mathrm{a}$ few for defense of property, ${ }^{91}$ and at least one consid-

${ }^{84}$ Id. at 192-93.

os See P.R. Laws Ann. tit. 33, $\$ 3154$ (1983) ("Transitory mental unsoundness caused purposely does not excuse criminal liability."); Wash. Rev. Code Ann. § 10.77.010(7) (Supp. 1984-1985) ("No condition of mind proximately induced by the voluntary act of a person charged with a crime shall constitute 'insanity." ").

${ }^{86}$ See N.H. Rev. Stat. Ann. $\S 626: 2($ II)(c) (1974) (person who creates a risk, but is unaware of it solely by reason of having voluntarily engaged in hypnosis, acts recklessly with respect to a material element of the offense).

${ }^{87}$ See, e.g., Alaska Stat. § 11.81 .440 (b) (1983) (duress defense unavailable when a person recklessly places himself in a situation where it is probable that he will be subject to duress); Ariz. Rev. Stat. Ann. $\S 13-412$ (B) (1978) (duress defense unavailable if the person intentionally, knowingly, or recklessly places himself in probable duress situation); N.J. Stat. Ann. $\S 2 \mathrm{C}: 2-9$ (b) (West 1982) (duress defense unavailable for any offense if actor recklessly places himself in probable duress situation, also is unavailable if the actor was criminally negligent in placing himself in such situation whenever criminal negligence establishes culpability).

Ba See, e.g., Colo. Rev. Stat. § 18-1-702(1) (1978) (choice of evils situation must have been occasioned or developed through no conduct of the actor); Del. Code Ann. tit. 11, $\S 463$ (1979) (choice of evils situation must have developed through no fault of the defendant); Hawaii Rev. Stat. $\S 703-302(2)$ (1976) (choice of evils defense is unavailable in a prosecution for an offense in which recklessness or negligence suffices to establish culpability if the actor was reckless or negligent in bringing about the situation requiring the choice).

${ }^{89}$ See, e.g., Ky. Rev. Stat. $\$ 503.060(2)$, (3) (1975) (self-defense is never available where defendant, with intention of causing death or serious injury, provokes the use of physical force and is unavailable where the actor is the initial aggressor unless the actor later withdraws); N.D. Cent. Code $\$ 12.1-05-03(2)$ (1976) (self-defense unavailable where person intentionally provokes uniawful action in order to cause bodily injury or death); Tex. Penal Code Ann. $\$ 9.31$ (b)(4) (Vernon 1974) (self-defense unavailable if actor provokes the unlaw. ful force).

so See, e.g., Del. Code Ann. tit. 11, §§ 464(e)(1), 465(a)(1) (1979) (actor must not have provoked the use of force so as to invoke defense of others with the purpose of causing 


\section{ers it for the judicial authority defense. ${ }^{92}$}

That even one jurisdiction considers an actor's causing the conditions of his defense suggests that at least one jurisdiction believes that the issue is relevant for that defense. Further, there are appellate cases in which an actor has caused the conditions of his defense for the defenses of involuntary act, ${ }^{93}$ duress, ${ }^{94}$ lesser evils, ${ }^{95}$ self-defense, ${ }^{86}$ insanity, ${ }^{87}$ defense of others, ${ }^{98}$ defense of property, ${ }^{98}$

death or serious physical injury); N.D. Cent. Code $\$ 12.1-05-04$ (1976) (defense of others available if actor has not, by provocation or otherwise, forfeited the right of sel(-defense); 18 Pa. Cons. Stat. Ann. \$\$ 505(b)(2)(i), 506(a)(1) (Purdon 1973) (for defense of others actor must not provoke force with intent of causing serious injury or death).

B1 See, e.g., Ind. Code Ann. $\$ 35-41-3-2(d)(2)$, (3) (Burns Supp. 1984) (defense of property unavailable to one who provokes unlawful action of another with intent to cause injury or to one who is the initial aggressor); Kan. Stat. Ann. $\S \S 21-3213,-3214(2),(3)$ (1981) (defense of property unavailable to person who initially provokes the use of force); P.R. Laws Ann. tit. $33, \S 3095$ (1983) (defense of property is available provided there is a lack of sufficient provocation by the actor).

${ }^{82}$ See Me. Rev. Stat. Ann. tit. 17-A, § $102(2)$ (A) (1983) (justification of judicial authority unavailable if the officer knowingly procured a defective order).

${ }^{93}$ See, e.g., Virgin Islands v. Smith, 278 F.2d 169, 175 (3d Cir. 1960) (on retrial, jury could consider whether defendant, an epileptic, knew at the time he drove that he might black out); Smith v. Commonwealth, 268 S.W.2d 937 (Ky. 1954) (defendant, who struck and killed a pedestrian while driving an automobile, knew he was subject to frequent blackouts while driving; the defense of no voluntary act was unavailable; citing, but not distinguishing, Fain v. Commonwealth, $78 \mathrm{Ky} .183$ (1879)); State v. Gooze, 14 N.J. Super. 277, 81 A.2d 811 (App. Div. 1951) (defendant had a history of blackouts from Méniere's Syndrome; defense of no voluntary act was unavailable where the defendant claimed he caused injury during a blackout while driving); see also supra text accompanying notes 83-84.

*4 See, e.g., People v. Bailey, 41 Colo. App. 385, 590 P.2d 508 (1978) (defendants intentionally or recklessly placed themselves in situation where it was foreseeable that they might be subject to force; thus duress was unavailable), aff'd, __ Colo. _, 630 P.2d 1062 (1981); Ross v. State, 169 Ind. 388, 82 N.E. 781 (1907) (compulsion must have arisen without the negligence or fault of the person who insists on it as a defense); State v. Clay, 220 lowa 1191, 1203, 264 N.W. 77, 83 (1935) (same) (citing Ross).

os See, e.g., People v. Perez, 97 Ill. App. 3d 278, 280-81, 422 N.E.2d 945, 947-48 (1981) (failure to instruct on lesser-evils defense proper where there was no evidence that defen. dant was without fault in bringing about the circumstances); State v. Diana, 24 Wash. App. 908, 913-14, 604 P.2d 1312, 1316 (1979) (defense unavailable where compelling circumstances were brought about by the defendant).

* See, e.g., United States v. Peterson, 483 F.2d 1222, 1231 (D.C. Cir.) ("The right of homicidal self-defense is granted only to those free from fault in the difficulty; it is denied to slayers who incite the fatal attack [or] encourage the fatal quarrel . . . ."), cert. denied, 414 U.S. 1007 (1973); Commonwealth v. Johnson, 460 Pa. 169, 176-77, 331 A.2d 473, 476 (1975) (defendant must be free from fault in provoking or continuing the difficulty to claim self-defense).

97 See, e.g., United States v. Henderson, 680 F.2d 659, 661-62 (9th Cir. 1982) (insanity brought about by voluntary intoxication is not a defense); United States v. Burnim, 576 F.2d 236 (9th Cir. 1978) (insanity defense unavailable to defendant whose insanity was the 
and judicial authority. ${ }^{100}$ Obviously, then, the issue of causing the conditions of one's defense can arise in all of these defenses. Thus, the failure of most jurisdictions to have comprehensive provisions to deal with this issue probably reflects inadvertence rather than a defensible conclusion that the issue will not arise except in the few situations specifically addressed by statute.

\section{G. Conclusion}

The problem of how to treat an actor who causes the conditions of his own defense has not yet received thoughtful or comprehensive treatment by judges or lawmakers. A defensible general principle is needed to govern all instances of an actor's culpability in bringing about the conditions of his defense. A single general principle would assure a consistent approach to different defenses. ${ }^{101}$ It would also assure that some mechanism existed to take account of such causing-one's-defense whenever it arose, for all defenses.

Part II of this article proposes such a general principle. It rejects all the existing approaches, even the sophisticated approach described in subsection $D$, because they ignore the most critical factor for determining the actor's appropriate liability: the actor's culpability as to committing the offense at the time he causes the conditions of his defense. As Part II demonstrates, a focus on an actor's conduct and culpability at the time of causing the condi-

product of voluntary intoxication); cf. State v. Maik, 60 N.J. 203, 215-16, 287 A.2d 715, 721 . 22 (1972) (although culpability in causing insanity was at issue, court refused to consider the etiology of the disease).

${ }^{98}$ See Shuck v. State, 29 Md. App. 33, 43-44, 349 A.2d 378, 384 (1975) (actor who is at fault in bringing on the difficulty may be entitled to an "imperfect" defense of others); Commonwealth v. McGuire, 487 Pa. 208, 217 n.4, 409 A.2d 313, 318 n.4 (1979) (for a defense of others, neither the person defended nor the defender may be at fault in provoking the difficulty) (citing Commonwealth v. Jackson, $467 \mathrm{~Pa}$. 183, 355 A.2d 572 (1976)).

9s See, e.g., Pierce v. Floyd, 38 Ale. App. 439, 86 So. 2d 658 (1956) (defense of property in a civil action is unavailable if defendant was at fault in bringing on the affray).

100 See, e.g., David v. Larochelle, 296 Mass. 302, 5 N.E.2d 571 (1936) (public authority justification available in a civil action where defendant was unintentionally at fault in causing arrest warrant to issue).

(10) The absence of such a general principle may reflect an insensitivity to the inconsistency prohlems discussed supra in subsections (E) and (F), or it may reflect the lack of consensus as to which of the approaches discussed supra in subsections (A) through (D) would make the best model for a general principle. Finally, although it seems highly unlikely, it may reflect unarticulated distinctions intentionally drawn to generate appropriate differences. 
tions of his defense, rather than on his conduct and culpability at the time of the offense, avoids nearly all of the problems noted in this Part and generates results that more closely approximate our collective notions of justice.

\section{A Proposal: Maintaining the Defense for the Offense Conduct but Imposing Liability for Conduct in Causing the Defense Conditions}

As Part I illustrates, the current treatment of an actor who is culpable in causing the conditions of his defense is inadequate in many troubling respects. Moreover, current law imposes liability on the actor through the theoretically unsound method of denying him a defense. This Part suggests an analysis that would continue to allow the actor a defense for the immediate conduct constituting the offense, but would separately impose liability on the basis of the actor's earlier conduct in culpably causing the conditions of his defense.

This alternative, "conduct-in-causing" analysis avoids the problems arising from current law treatment and has several advantages. It avoids the anomaly of denying a justification or excuse to an actor who satisfies the conditions of those defenses. It avoids the improper assumption that an actor who intends to cause (or risks causing) the conditions under which an offense is committed necessarily intends to commit (or risks committing) the offense. It also properly distinguishes among levels of culpability at the time of causing one's defense in determining the level of liability to be imposed.

\section{A. Maintaining the Defense Although the Actor Has Caused Its Conditions}

Where conduct is justified because it avoids a net harm for society, it provides little basis on which to fasten blame and it is against society's interest to deter it. Where a forest fire has been set, for whatever reason, society wants any and all persons to set a firebreak and save a threatened town. ${ }^{102}$ To withdraw a defense for such conduct is to punish and to discourage it.

102 For an analogous argument in the context of the unknowingly justified actor, see Robinson, A Theory of Justification: Societal Harm as a Prerequisite for Criminal Liability, 
Assume that an actor sets a fire that threatens a nearby town to create the conditions that will justify his using his enemy's farm as a firebreak. Denying a justification defense might dissuade him from undertaking such a scheme, but if it fails to dissuade him, the unavailability of the defense may reduce his incentive to set the firebreak and save the town. Once the justifying conditions exist, regardless of the cause, society benefits if the actor undertakes the justified conduct. Moreover, if the defense is denied, the owner of the field, who values his crop more than he does the lives of the townspeople, may lawfully interfere with the actor's attempt to set fire to the field.

Denying the defense to the actor who has created the justifying circumstances also creates an anomalous situation in which the actor and another person may work side-by-side engaging in the same conduct-here, setting fire to the same field-yet one will be justified and the other will not. It is the nature of justified conduct that it either is or is not justified--depending on whether it causes a net societal benefit-regardless of the particular state of mind, past or present, of the actor. ${ }^{103}$

These problems may be avoided, however, and such a grand schemer may be properly punished, if his liability is based on his initial conduct in causing the justifying circumstances and on his culpable state of mind, at that time, as to causing the justified harm. ${ }^{104}$ In the culpably-caused-need-for-a-firebreak case, the actor might be liable for setting the forest fire in the first place and for the damage it caused. His subsequent conduct in saving the town by setting the firebreak would remain justified, and thus would be encouraged and protected. ${ }^{105}$ Indeed, the actor retains a special incentive to set the firebreak, for if the town burns down and kills or injures someone, he may be be liable for this additional harm.

23 UCLA L. Rev. 266, 284-92 (1975) [hereinafter cited as Robinson, A Theory of Justification].

${ }^{209}$ For a discussion of the attributes of justified conduct, see Robinson, A Systematic Analysis, supra note 3 , at $274,279-80$.

${ }^{104}$ The precise means of defining the actor's liability will be set forth in subsection $C$.

${ }^{105}$ Similarly, where a speeder must choose between hitting two pedestrians or damaging a grocery store, he may be justified in veering off toward the store. $\mathrm{He}$ should not escape liability entirely, however, because his speeding is properly viewed as an intentional creation of a risk of injury to persons or property. He may properly be held liable for reckless destruction of property. The destruction itself is justified; it is his earlier creation of the risk on which liability may be imposed. 
As with justifications, there is a fundamental flaw in an approach that denies an excuse because the actor culpably causes the conditions of his excuse. Just as causing one's defense does not alter the justified nature of otherwise justified conduct, it does not erase the excusing conditions that exculpates the actor for the offense conduct. If an actor is not responsible when a recognized disability causes an excusing condition for his actions, it follows that he is equally not responsible at the moment of the same offense conduct under similar conditions, even though he has contributed to their creation. To punish an actor for conduct performed when he is not responsible is to punish him for conduct that society has determined to be beyond his control and thus blameless. ${ }^{106}$ Punishing blameless conduct undercuts the condemnation and credibility of the criminal justice system. In short, the reasons for initially providing an excuse remain the reasons for retaining it whenever the excuse conditions are met. ${ }^{107}$ It remains appropriate, however, to punish the actor based on his initial conduct in causing his excuse conditions.

\section{B. Existing Offenses that Punish Conduct Causing the Conditions of a Defense}

Sometimes, an actor's conduct in bringing about the conditions of his defense will be criminal. For example where an actor is criminally negligent in causing a forest fire, he may be convicted of criminally negligent burning in some states (of the forest burned by his initial conduct). ${ }^{108}$ Where he intentionally starts the fire, he may be convicted of arson. ${ }^{108}$ Some jurisdictions have specialized offenses to punish one who provokes an assault or procures a false warrant. ${ }^{110}$ Similarly, voluntary intoxication is often an offense, at

${ }^{106}$ For a more detailed discussion, see Robinson, A Systematic Analysis, supra note 3, at 221-29; see also supra note 5 (describing excuse defenses in general).

${ }^{107}$ The same conclusion is appropriate no matter what one's theory is for permitting an excuse. See generally A. Goldstein, The Insanity Defense 11, 16 (1967) (arguing that each of the theories underlying criminal law-deterrence, retribution, and rehabilitation-justifies punishment of actors other than those who are capable of choosing how they will behave).

${ }^{108}$ E.g., Alaska Stat. § 11.46.400 (1983).

${ }^{108}$ More precisely, he may be convicted of arson if he was additionally reckless as to placing another person, such as a firefighter or camper, in danger of serious injury. Id.

110 See, e.g., Ind. Code Ann. $\$ 35-42-2-3$ (Burns 1979) (provocation criminalized); Evans 
least where such intoxication is public. ${ }^{111}$ Several jurisdictions have also defined offenses punishing those who engage in certain activities or who cause certain harms while intoxicated. ${ }^{112}$

There is not always an offense, however, that punishes the conduct that causes the defense conditions. Statutes rarely prohibit hypnotization, for example. Similarly, Supreme Court cases clearly establish that one may not be punished for a mere "status offense" such as being addicted to intoxicants. ${ }^{113}$ These status offense concerns, however, do not apply to conduct that causes the conditions of a defense. In any case, reliance only on the criminalization of conduct that causes a defense is inadequate in most cases. Even if this liability is available, it fails to account for different levels of culpability as to committing a subsequent offense and for variations in the seriousness of the subsequent offense.

\section{A General Principle of Liability for an Actor Who Culpably Causes the Conditions of His Defense}

Where an actor brings about the conditions of his defense but at the time has no culpability, not even negligence, as to causing or risking the commission of the subsequent offense, it is appropriate to limit his liability to that imposed by existing statutes. If his conduct constitutes negligent property destruction or being drunk in

v. State, __ Ind. App. __ 434 N.E.2d 940 (1982) (upholding $\$ 35-42-2-3$ against vagueness attack); accord C.Z. Code tit. 6 , $\$ 271$ (1962) (malicious procurement of warrants criminalized); V.I. Code Ann. tit. 14, § 221 (1964) (same).

${ }^{111}$ See, e.g., Del. Code Ann. tit. 11, $\$ 1315$ (1979) (public intoxication unlawful); Model Penal Code $\$ 250.5$ (Proposed Official Draft 1962) (same).

112 Several provisions appear to ensure punishment of one who causes an excusing condition by punishing those who engage in certain activities while intoxicated. See, e.g., Alaska Stat. \$ 11.61.210(a)(1) (1983) (possessing, on one's person, a firearm while intoxicated); Colo. Rev. Stat. § 18-12-106(1)(d) (Supp. 1984) (same); La. Rev. Stat. Ann. § 14:98 (West Supp. 1984) (operating vehicle while intoxicated); Mich. Comp. Laws Ann. \$ 750.167a (West 1968) (hunting while intoxicated); Mo. Rev. Stat. $\$ 577.010 .1$ (Cum. Supp. 1983) (operating vehicle while intoxicated).

Some jurisdictions also have special statutes governing harms caused while intoxicated. See, e.g., Colo. Rev. Stat. § 18-3-205(1)(b)(I) (Supp. 1984) (causing serious bodily injury to another by driving under the influence of an intoxicant; strict liability); Md. Ann. Code art. 27, § 388A (1982 \& Supp. 1984) (homicide by motor vehicle while intoxicated); Mo. Rev. Stat. \& 577.005 (Cum. Supp. 1983) (negligently causing death while driving in an intoxicated state); Wis. Stat. Ann. $\$ 940.09$ (West 1982 \& Supp. 1984-1985) (homicide committed due to intoxicated use of a vehicle or firearm).

${ }^{113}$ Robinson v. Californis, 370 U.S. 660, 666-67 (1962); Powell v. Texas, 392 U.S. 514, 533 (1968) (Marshall, J., plurality opinion) (explaining Robinson). 
public, then such offenses are properly the extent of his liability. If his conduct does not constitute an offense, he faces no liability.

Where the actor is not only culpable as to causing the defense conditions, but also has a culpable state of mind as to causing himself to engage in the conduct constituting the offense, the state should be punish him for causing the ultimate justified or excused conduct. ${ }^{114}$ His punishment, however, is properly based on his initial conduct of causing the defense conditions with his accompanying scheming intention, not on the justified or excused conduct that he subsequently performs.

Under this analysis, one need simply consider whether, at the time that the actor engages in his initial conduct in causing the defense conditions (for example, starting the forest fire), he has a culpable state of mind as to causing the conduct constituting the offense (i.e., burning the firebreak). For example, if when the defendant sets the forest fire, his ultimate objective is to create the conditions that will permit him (or anyone else) to burn the firebreak, he is properly held liable for intentionally causing the burning of the firebreak. His liability is based on his conduct of setting the forest fire with his accompanying intention to cause the burning of the firebreak, not on his justified burning of the firebreak. $\mathrm{He}$ is then liable for the result that he has intentionally caused, yet all persons are still justified in burning the firebreak. ${ }^{115}$

114 This occurs in a "grand schemer" case, for example, where the actor intends to create the defense conditions to then commit the defense. It is no doubt the concern for the "grand schemer" that creates a hesitation to provide an excuse when an actor has culpably caused the disability and excusing conditions. As one court complained: "All that the crafty criminal would require for a well-planned murder . . . would be a revolver in one hand to commit the deed, and a quart of intoxicating liquor in the other with which to build his excusable defense." State v. Arsenault, 152 Me. 121, 130-31, 124 A.2d 741, 746 (1956). Perhaps the "grand schemer" best known in the popular culture is the vigilante character of the 1974 movie "Death Wish," who deliberately takes late-night walks and subway rides to place himself in threatening situations where he could kill the muggers who tried to attack him.

115 There is some legislation designed to punish the grand schemer in the manner sug. gested here. At least one jurisdiction punishes as a murderer one who perjures himself with intent to bring about circumstances justifying the execution of an innocent person. Colo. Rev. Stat. $\$ 18-3-102(1)(c)$ (1978); cf. statutes cited supra note 110 (punish only for the conduct causing the justifying circumstances).

One might argue that the conduct of a grand schemer in causing the justified burning of the field should give rise to liability for only attempied property destruction. Like the unknowingly justified actor, this actor intended to cause a legally-recognized net harm and acted upon that intention, but caused only a justified harm. See generally Robinson, A The- 
This approach has the additional advanlage of holding an actor liable for burning the firebreak when his grand scheme causes others to burn the firebreak, rather than limiting such liability, as current law tends to do, to the situation where he personally burns it. ${ }^{118}$ In addition, under this analysis the actor and all others are encouraged to perform the justified conduct. ${ }^{117}$ Finally, this analysis accounts for different degrees of culpability as to the ultimate

ory of Justification, supra note 102 , at $288-91$ (discussing attempt liability for the unknowingly justified actor).

There are valid objections, however, to imposing only attempt liability on one who culpably creates justifying circumstances. First, it would give to an actor bent on crime a device to limit his liability to an attempt to commit the offense, simply by creating circumstances that would justify his conduct constituting the offense. (He would also be liable for any offense committed while creating the justifying circumstances, for example, setting a forest fire, but as noted in the text of this subsection, the conduct in causing is not always an offense.)

Second, the situation is not really analogous to that of the unknowingly justified actor. There, no net harm has been caused, except for the harm or evil of the bad intention that the unknowingly justified actor acted upon. Here, however, in considering whether there is a net harm, one must look at the time before the actor engaged in the conduct creating the justifying circumstances. From this perspective, the actor's conduct in creating the justifying circumstances did create a net harm-he engaged in conduct that ultimately caused the burning of the firebreak at a time when there was no justification for such conduct. He has thus caused two harms: (1) the immediate harm-the forest fire, and (2) the harm of the justified conduct necessary to combat the forest fire-the firebreak. The burning of the firebreak is justified because under the circumstances as they then exist, the harm of the firebreak avoids a greater harm. The firebreak, however, is a harm necessitated by the actor's initial conduct. Nor would attempt liability be sufficient where the actor culpably causes an excusing condition; excused conduct does cause a harm or evil. See Robinson, A Systematic Analysis, supra note 3, at 229 (arguing that acts of the excused are socially harmful, but such actors do not merit punishment).

${ }^{116}$ For example, the Model Penal Code provides a justification defense to one who believes the person whom he assists is entitled to protect himself. Model Penal Code $\S 3.05(1)$ (b) (Proposed Official Draft 1962). There is no readily apparent means of holding a provoker liable for the conduct of one who comes to the provoker's assistance when the person provoked attacks the provoker. One might, however, argue that id. $\S 2.06(2)(a)$ ("Liability for Conduct of Another; Complicity") imposes liability on the theory that the provoker caused an innocent person to engage in the conduct and is therefore accountable for the conduct.

117 The actor generally has an incentive to engage in the justified conduct himself and assure that the greater harm is avoided. If he fails to do so, he will increase his own liability. Where the firebreak is not burned, for example, he may be held liable for the death and destruction of the entire town. Liability will be based either on his initial conduct in setting the forest fire and creating a risk of such death and destruction or, under an omission theory, on his failure to act to avoid the harm when he could have done so at little risk to himself and where he had a duty to do so because he created the danger. The Model Penal Code contains a provision to cover this situation. Id. $\$ 220.1(3)(b)$ (actor who starts a fire commits a misdemeanor if he knows that the fire is endangering life or substantial amounts of property and fails to take reasonable steps to put it out). 
offense. If at the time of starting the forest fire the actor is only aware of a risk that his conduct will cause him (or others) to burn the firebreak, he is properly held liable only for recklessly causing the destruction of the firebreak.

The same analysis is appropriate when an actor causes the conditions of an excuse. He may properly be held liable for the ultimate offense on the basis of his causing the excused conduct and his accompanying culpable state of mind with respect to his commission of the ultimate offense. Thus, where the actor arranges for a hypnotist to give him an hypnotic suggestion to kill his wife, the actor may be liable for intentionally killing his wife. He is liable not on the basis of his conduct of killing her while in an hypnotic state, as that conduct is excused, but instead on the basis of his earlier, unexcused conduct of seeking to be hypnotized with the intention of thereby causing the subsequent death of his wife.

An actor may be culpable as to causing the ultimate offense when he causes the disability-for example, by going to the hypnotist--or when he fails to terminate or at least to make allowance for a preexisting disability. Assume that an epileptic fails to take his anti-seizure medicine, and during a seizure in an elevator he strikes and injures two people. His liability is properly determined by asking whether, at the time he failed to take his anti-seizure medicine, he was aware that this failure might subsequently cause physical injury to others. If so, he should be liable for reckless assault. If he intended to injure these people he can be convicted of intentional assault. Under this analysis, the defendant in Fain $v$. Commonwealth, ${ }^{118}$ who had a disorder that made him violent when aroused from sleep, could have been punished for his "breach of social duty in going to sleep in the public room of a hotel with a deadly weapon on his person."118 Because he "no doubt [knew] his propensity to do acts of violence when aroused from sleep,"120 he could properly have been held liable for reckless homicide based on his earlier conduct of going to sleep in a public place with a gun in his lap.

As in the justification situation, this approach is also useful because it establishes that an actor who causes excusing conditions is

\footnotetext{
$11878 \mathrm{Ky} .183$ (1879); see supra notes $83-84$ and accompanying text.

118 Fain, $78 \mathrm{Ky}$. at 192.

$120 \mathrm{Id}$.
} 
liable for the resulting harm no matter who actually engages in the excused conduct. For example, the result in the hypnosis hypothetical would be the same whether the defendant employs the hypnotist to compel the defendant himself or to compel another to kill the defendant's wife. There is clear precedent for holding people liable for causing irresponsible agents to engage in otherwise criminal conduct. ${ }^{121}$ There is no reason why the analysis should change if instead of causing another person to perform the conduct, the actor causes himself to perform it.

Furthermore, this analysis properly accounts for different degrees of culpability as to the ultimate criminal conduct. If at the time of causing the conditions of the excuse the actor is reckless as to ultimately causing a death, he may properly be held liable for reckless homicide. If the actor should know, but does not, that.a notoriously insane hypnotist may give him a hypnotic suggestion to kill, the actor is negligent as to the death when he undergoes hypnosis and kills pursuant to such a suggestion. ${ }^{122}$

This analysis is similarly useful when the excuse at issue is mistake as to a justification. Suppose a police officer with poor eyesight decides not to wear his glasses on the job. As a consequence, he mistakenly believes that an arrestee is threatening him with a gun, and because of his misperception he unjustifiably kills the arrestee. The proper question in assessing liability is whether, at the time he decided not to wear his glasses, the officer was aware of the risk of such an error and of the consequences of the error. If he was reckless as to making such an exculpatory mistake and thereby

${ }^{191}$ See, e.g., Moore v. State, 267 Ind. 270, 277, 369 N.E.2d 628, 632 (1977) ("At common law, one who caused an act to be committed by an innocent agent was guilty of the act himself."); Attorney-Gen. Reference (No. 1 of 1975) 61 Crim. App. 118 (1975) (one who spiked another's drink and thus caused the other's drunk driving would be guilty of "procuring" drunk driving); 18 U.S.C. $\$ 2$ (b) (1982) (actor who willfully causes an act to be done that would be an offense if directly committed by the actor is guilty of an offense); Wyo. Stat. § 6-1-116 (1977) (one who causes another's involuntary intoxication is liable for the offense) (repealed P.L. 1983, Ch. 171); Model Penal Code $\S 2.06(2)(a)$ (Proposed Official Draft 1962) (a person is accountable for the conduct of an innocent or irresponsible actor if he culpably causes that conduct); cf. Colo. Rev. Stat. \$ 18-5-116 (Supp. 1984) (fourth degree felony to intoxicate another by trick).

${ }^{122}$ A third useful characteristic of this analysis is that where the ultimate offense is never committed, the defendant may nonetheless be liable for an attempt to commit the offense. For example, where the hypnotist refuses to carry out the actor's request and reports the request to the police, the actor may be held liable for attempted murder. This result is consistent with normal attempt theory. 
causing this result when he chose not to wear his glasses, he may properiy be convicled of reckless homicide. ${ }^{123}$

A final example of the propriety of the foregoing analysis is a failure of proof defense where an actor's voluntary intoxication negates an offense element. The actor's liability for the offense may be based on his conduct at the time he becomes voluntarily intoxicated and his accompanying state of mind as to the elements of the subsequent offense. If he intoxicates himself with the intention of committing a robbery while intoxicated, ${ }^{124}$ he would be liable for the crime even though at the time of the robbery he might not have had the required state of mind.

This analysis has advantages analogous to those illustrated in the context of general defenses. For example, it properly accounts for different levels of culpability as to causing the subsequent offense. Assume an actor knows that he always beats his wife uncontrollably after he returns from drinking with his buddies and that he knows that the severity of the beating is directly proportional to the extent of his drinking. He decides to kill his wife, goes to the bar intending to drink heavily to cause the desired beating, and returns home and uncontrollably beats his wife to death. The evidence suggests that at the time of the beating, because of his gross intoxication, he was unaware of a risk that his conduct would kill his wife. He may not even have been aware of his conduct. The Model Penal Code would permit his intoxication to negate purpose or knowledge as to the death of his wife; it would impute recklessness and thereby convict him of reckless homicide (manslaugh-

123 This analysis is necessary because the actor would probably gain a mistake as to a justification defense otherwise. The Model Penal Code deprives an actor of a defense only if he is reckless or negligent at the time of the mistake as to a justification. Model Penal Code $\S 3.09$ (2) (Proposed Official Draft 1962). Both recklessness and negligence are assessed from the viewpoint of a person in the actor's situation, which would include bad eyesight. See id. $\S 2.02(2)(\mathrm{c})$, (d).

One might argue, however, that the police officer loses the defense because, when he failed to wear his glasses, he was reckless or negligent in "failing to acquire any knowledge or belief which is material to the justifiability of his use of force." Id. \$ 3.09 (2). Yet that provision was probably intended to apply only when the actor is faced with a possibly justificatory situation, but has sufficient time to make appropriate inquiries and fails to do so. The Commentary to $\S 3.09(2)$ is unhelpful in clarifying this issue. See Model Penal Code $\S 3.09$ comment 2 (Tent. Draft No. 8, 1958). Moreover, there seem to be no reported cases addressing this issue in the states that have enacted this provision of the Code.

${ }^{124}$ This situation existed in DeBerry v. Commonwealth, 289 S.W.2d 495, 496 (Ky.), cert. denied, 352 U.S. 881 (1956). 
ter). ${ }^{128}$ It seems clear, however, that a conviction for an intentional killing (murder) would be appropriate here. The proposed causingone's-defense analysis would hold the actor liable for murder, based on his conduct in causing his intoxication and his then-existing intention to kill his wife.

Not only does the proposed analysis avoid treating such a grand schemer too leniently, but it also protects a less-culpable actor from being treated too harshly. The Model Penal Code would impute recklessness to the drinker who at the time of his imbibing is unaware of any risk that he may kill or even beat his wife and thus would convict him of reckless homicide. The proposed analysis would avoid such an unwarranted result. The jury would examine his state of mind as to killing his wife at the time he began to drink and would probably conclude that at that time he was at most negligent as to causing his wife's death. He would thus be liable for, at most, negligent homicide. Indeed, a jury might conclude that a reasonable person under the same circumstances might have been unaware of a risk of causing his wife's death; thus, the actor might escape liability even for negligent homicide. ${ }^{126}$

\section{Precedent for a Principle of Liability for Causing the Conditions of One's Defense}

This Part's focus on the actor's earlier conduct and his accompanying culpability as to the ultimate offense, rather than on the conduct and culpability most immediately associated with the offense, is analogous to liability for causing a crime by an innocent. The analysis simply generalizes the latter principle and treats the justified, excused, or unaware actor as the "innocent actor" who was caused to engage in the criminal conduct by the actor's prior, culpable actions. Thus, the statutes and cases imposing liability for such causing-crime-by-an-innocent ${ }^{127}$ provide a certain measure of support for the principle proposed here of liability for causing the conditions of one's defense.

126 See Model Penal Code § 2.08(2) (Proposed Official Draft 1962).

${ }^{124} \mathrm{He}$ might be liable, however, if his earlier conduct is itself an offense, such as public intoxication, or if he satisfies at the time he began to drink, the requirements of any other offense, such as negligently endangering others.

${ }^{127}$ For citations to such cases and statutes, see Robinson, Imputed Criminal Liability, supra note 22 , at $631-32 \mathrm{nn} .71-76$. 
The present analysis is also entirely consistent with the normal operation of criminal liability rules of causalion. Assume that the actor's car accelerator has recently been sticking momentarily. Being a seasoned auto mechanic, she realizes that the accelerator could become stuck in the full-throttle position. In such an emergency, she would need at least thirty seconds to slow her car and would therefore be unable to respond if another car or a pedestrian suddenly crossed her path. She reasons that because she will be driving on a straight and open highway she is unlikely to face any emergency that will require her to react quickly. In the middle of her excursion, the accelerator becomes stuck, and while she is trying to release it, she sees a line of school children crossing the highway during a nature outing. Because of her rapidly increasing speed, she cannot avoid the children and kills four of them. Assume that at the time of the killing she is truly helpless to avoid the children. Although she is not affirmatively "taking a risk" at the time of the offense (in the sense that she is consciously choosing to drive that fast-she has no choice at that point), we can nevertheless hold her liable for reckless, or at least negligent, homicide. This liability would be based on her earlier conduct of setting in motion the chain of events-culpably causing the conditions-that led to the four deaths.

From a narrow time perspective the driver is blameless for the deaths, because the car was out of her control at the time of the offense. Her preceding act of driving with the defective accelerator was reckless, however, as to causing the deaths of pedestrians. By broadening the time perspective to include the earlier conduct and its accompanying culpability as to the ultimate harm, one may then properly impose liability for the deaths despite the driver's inability to avoid the harm at the time it actually occurred. ${ }^{18}$ This use of traditional causation rules is analogous to the proposed

128 Indeed, one might argue that the Model Penal Code provisions on causation and criminal homicide are already adequate to allow such a finding of liability. A person who recklessly "causes the death of another human being" is guilty of manslaughter, Model Penal Code $\S 210.1, .3(1)(a)(1980)$, and the requirements as to causation might be open-ended enough to allow such a finding of causation in some cases. See id. $\S 2.03(1)$, (3) (Proposed Official Draft 1962). It is likely, however, that without a special rule expressly permitting liability under such a causing-one's-defense analysis, the causation requirement might frequently be held to be unsatisfied, i.e., the ultimate offense might be "too remote" from the actor's conduct in causing the conditions of his defense for the actor to be held accountable for the offense. 
causing-the-conditions analysis.

There is case law precedent for the causing-one's-defense analysis proposed here. ${ }^{129}$ In the civil case of David $v$. Larochelle, ${ }^{130}$ for example, the defendant sheriff failed to complete the summons form that required plaintiff to appear in court; he indicated neither the plaintiff's name nor the time for his appearance. When the plaintiff failed to appear, the defendant, unaware of his own error, arrested him for his nonappearance. The plaintiff subsequently sued for assault and false arrest. The court held that the defendant sheriff's error had no effect on the legality of the arrest and that the arrest was therefore justified.

The holding in Larochelle is consistent with the rule proposed here: conduct that is otherwise justified should remain justified even though the actor may have been culpable in bringing about the justifying circumstances. The actor, however, should not necessarily escape liability for his conduct in creating the justifying circumstances. Larochelle is also consistent on this point. The sheriff was liable for the damages resulting from his negligent failure to complete the summons properly. ${ }^{131}$

${ }^{20}$ See, e.g., State v. Butner, 66 Nev. 127, 135, 206 P.2d 253, 257 (1949) (person who drinks to nerve himself before committing a crime cannot maintain that he was too drunk at the time of the offense to entertain the requisite intent), cert. denied, 338 U.S. 950 (1950); see generally R. Perkins \& R. Boyce, Criminal Law 1008-09 (3d ed. 1982) (where premeditation and deliberation occur before the defendant causes his excusing intoxication, the defendant is properly held liable for the offense perpetrated); Model Penal Code $\$ 2.08$ comment 3 , at 7 (Tent. Draft No, 9, 1959) (noting that those who objected to the Model Penal Code formulation of the intoxication negating an element defense, which is discussed supra notes 45-51 and accompanying text, argued that the voluntarily intoxicated actor's liability could be based on the actor's awareness of the harm risked at the time he became intoxicated).

In Taylor v. Superior Court, 3 Cal. 3d 578, 477 P.2d 131, 91 Cal. Rptr. 275 (1970), the court would not hold the defendant directly liable under the felony-murder rule for the justifiable killing of one of his co-felons by the owner of a store that the defendant and his co-felons were robbing. The court was willing, however, to permit an imputation of liability under a theory of vicarious liability. It focused on the co-felon's earlier conduct of initiating the gun battle that cauged the justifying circumstances. Under the analysis proposed in the text, however, where the actor intentionally causes the justifying circumstances but is only reckless as to whether a justified killing will result, as the Taylor court conceded to be the case there, id. at $582-83,477$ P.2d at 133,91 Cal. Rptr. at 277 , the defendant may properly be held liable only for reckless homicide. The contrary result in Taylor may be due to the special aggravation of culpability aspect inherent in the felony-murder rule. See generally Robinson, Imputed Criminal Liability, supra note 22, at 623-25 (discussing the felony-murder rule).

130296 Mass. 302, 5 N.E.2d 571 (1936).

13) The plaintiff was denied recovery, however, under theories of false arrest and assault. 
In a Tennessee case, the court used a similar analysis to hold the defendant liable for murder even though his voluntary intoxication at the time of the offense indicated that he lacked the recklessness necessary for a murder. The court focused on the defendant's earlier conduct and his accompanying state of mind at the time that he caused the conditions of his intoxication defense. ${ }^{\mathbf{1 3 2}}$

Another case where the court relied on the defendant's culpability in causing the conditions of his excuse is State $v$. Gooze. ${ }^{133}$ Gooze had a history of blackouts from Meniere's Syndrome. While he was driving, he suffered a blackout and ran over a pedestrian. He was convicted of "caus[ing] the death of another by driving [a] yehicle carelessly and heedlessly in willful or wanton disregard of the rights or safety of others."134 The court noted that "[i]t was reasonably foreseeable that if he 'blacked out' or became dizzy without warning, its probable consequence might well be injury or death to others." The court then reasoned, "while one cannot be liable for what he does during the unconsciousness of sleep, he is responsible for allowing himself to go to sleep" while driving. ${ }^{135}$

These torts generally require that the defendant intend the injury, and the sheriff was at most only negligent when he failed to complete the summons.

332 The court stated:

It is inconceivable that a man can get as drunk as Edwards was on that occasion without previously realizing that he would get in that condition if he continued to drink. But he did continue to drink and presumably with knowledge that he was going to drive his car back to, or close to, Lebanon over this heavily traveled highway. He knew, of course, that such conduct would be directly perilous to human life. From his conduct in so doing, it was permissible for the jury to imply "such a high degree of conscious and willful recklessness as to amount to that malignity of heart constituting malice."

Edwards v. State, 202 Tenn. 393, 398, 304 S.W.2d 500, 503 (1949) (quoting Owen v. State, 188 Tenn. 459, 468, 221 S.W.2d 515, 519 (1957)). This case is cited in Model Penal Code $\S 2.08$ comment 3 , at 7 (Tent. Draft No. 9, 1959) to illustrate the point that "liability may still arise in . . a case [where an actor's voluntary intoxication negates recklessness at the time of the offense] based on the actor's awareness of risk while getting drunk, as when he knows that he must ultimately drive a car." Id. The approach has also been employed where the actor causes a provocation defense. See, e.g., State v. Manus, 93 N.M. 95, 100, 597 P.2d 280,285 (1979) (if defendant intentionally caused the decedent to do acts that the defendant could claim provoked him, he cannot claim provocation, as his conduct shows malice aforethought).

19314 N.J. Super. 277, 81 A.2d 811 (App. Div. 1951).

${ }^{134}$ Id. at $280,81 \mathrm{~A} .2 \mathrm{~d}$ at 813 .

${ }^{130}$ Id. at 286, 81 A.2d at 816; accord Virgin Islands v. Smith, 278 F.2d 169, 175 (3d Cir. 1960) (on retrial, jury in an involuntary manslaughter case could consider whether defendant, an epileptic, knew at the time he drove that he might blackout). 
E. The Problem of Otherwise Lawful Conduct that Would Be Punished Under Liability for Causing One's Own Defense

Where an actor's conduct that causes the conditions of his defense is an offense-for example, negligent burning or public drunkenness-there is little difficulty in imposing additional liability, as proposed in this Part, if the actor causes those conditions with some culpability toward causing himself thus to engage in further proscribed conduct, albeit justified or excused. ${ }^{138}$ Where the conduct causing the conditions of a defense is otherwise lawful, however, there may be some question as to whether the actor's lawful conduct may be used as the basis for criminal liability; after all, his conduct does not appear to satisfy the conduct requirements of any specified offense. In the hardest case, his conduct may be of a nature that is constitutionally protected.

Assume that a known member of the Palestine Liberation Organization enters a meeting of the Jewish Defense League being held in a public place. Assume further that his purpose in doing so is to induce, by his mere presence, the attendees to assault him, thereby creating the circumstances that will justify his use of force against them in self-defense. One might be inclined not to punish his conduct in causing the circumstances justifying his use of force because that conduct-entering the public meeting-is otherwise lawful. Courts have said, for example, in speaking of fault in causing the conditions of justifications, that "[f]ault implies misconduct," such as being where one has no legal right to be. ${ }^{137}$

This attitude, however, betrays a conception of criminal law according to which conduct is per se either legal or illegal, and fails to accept the relevance of context in assessing an act's criminality. Almost any act, even a homicidal one, may be legal in certain situations; an execution is an obvious example, as is self-defense. Similarly, an act that is usually legal may be criminal in certain situations; for example, driving along a highway may be illegal if it causes the death of a pedestrian standing in the middle of the road.

Even when similar acts are performed in similar situations, the actor's state of mind as to the consequences can be determinative

136 For examples of instances where conduct causing one's defense is criminalized, see supra notes $108-12$ and accompanying text.

137 State v. Jackson, 94 Ariz. 117, 122, 382 P.2d 229, 232 (1963). 
of criminality. An actor who comes into control of property that he knows was lost by another but who fails to report his finding is not guilty of theft unless he intended to deprive the owner of the property. ${ }^{138}$ A person who "antiques" his dining room furniture is not guilty of a crime unless he intends to defraud someone into buying it at an inflated price. ${ }^{139} \mathrm{~A}$ more important example of where otherwise legal acts can be the basis for criminal liability if performed with a particular state of mind is criminal attempt. An actor who has tools in his possession can be convicted of attempt if he intends to use them to commit a burglary. ${ }^{140} \mathrm{By}$ analogy, therefore, an actor may be criminally liable for entering a room of hostile people and eventually causing a justified killing if he did so with the appropriate state of mind as to causing that consequence.

To take a less dramatic example than the P.L.O./J.D.L. case, consider the actor, $D$, who sends $T$ a false letter claiming that he, $D$, is in possession of a watch that $T$ treasures. $D$ knows that the watch was recently stolen and that $T$, a person of violent temper, will on receipt of the letter unjustifiably attack him in an attempt to recover the watch. $D$ knows nothing of the whereabouts of the watch, but has devised this grand scheme to permit him to kill $T$ in self-defense. $D$ 's conduct in sending the letter is not itself unlawful. Because he did it with the intent to kill $T,{ }^{141}$ however, one may be inclined to hold him liable for murder, or at least attempted murder. ${ }^{142} \mathrm{His}$ liability would be based on his conduct in causing the attack, not on his justified defensive force.

One might have the same view toward the P.L.O. member who enters the J.D.L. meeting with a grand scheme of injuring the at-

${ }^{138}$ See, e.g., Model Penal Code $\$ 223.5$ (Proposed Official Draft 1962) ("Theft of Property Lost, Mislaid, or Delivered by Mistake").

${ }^{336}$ See, e.g., id. $\S 224.2$ ("Simulating Objects of Antiquity, Rarity, Etc.").

${ }^{140}$ See, e.g., id. $\S 5.01(1)(c),(2)$.

14 Note that if the letter-sender or the P.L.O. member intends only to create the opportunity for a justified assault in self-defense, but ends up killing in self-defense, he may be held liable for the degree of homicide consistent with his culpable state of mind with regard to causing the death. For example, by intending an assault, he may be aware of a risk of causing death, and thus be liable for reckless homicide. Cf. statutes cited supra notes 34,38 (denying the defense for homicide even if the actor intended only to create circumstances justifying assault).

142 Although one might argue that his conduct is only of the attempt variety because he has not at the time of the offense caused a net harm that the law punishes as a substantive offense, this argument is easily countered by considering the course of conduct. See supra note 115 . 
tendees in self-defense. The letter-sending case may seem a stronger one for criminal liability because the P.L.O. member is exercising an affirmative right of all citizens to go where they choose in public places, whereas the letter-sender has no affirmative right to mail false letters. It seems questionable, however, to distinguish noncriminal acts according to how offensive or desirable they may be. ${ }^{143}$ The better conclusion may be that although one may generally sympathize with the P.L.O. member's exercise of his rights to move freely in a public place, he has, by his intention to kill, acted just as improperly as the sender of the false letter. It may be more difficult to prove a grand scheme intention by the P.L.O. member than by the letter-sender, whose actions may speak for themselves, but where such an intent is proven, it is an adequate basis for liability, even though the underlying conduct is otherwise lawful.

\section{F. Defenses to Liability for Causing One's Own Defense}

Like conduct constituting an offense, an actor's conduct in causing the conditions of his defense may be blameless under a variety of defenses. If his conduct is entirely accidental-as when an actor provokes an attack when he takes property that he mistakenly but reasonably believes to be his own-his accidental conduct will not satisfy the culpability requirements of the liability principle proposed here. This outcome is analogous to the typical failure of proof "defense" where an actor's lack of culpability negates a culpable state of mind required by an offense definition. Here, the liability principle requires a culpable state of mind as to causing the resulting offense. ${ }^{1 * 4}$

Even if the actor does satisfy the culpability requirements for causing-one's-defense liability, he should nonetheless be entitled to any appropriate general defense to such liability. For example, an actor may have set a forest fire as a justification for later burning a firebreak, but may have done so only because he was coerced, thereby meriting a duress excuse for his causing the justificatory

${ }^{143}$ Travel in interstate or foreign commerce is generally lawful, and interstate travel is often considered a constitutional right, but such travel becomes a federal crime when done with the intent to avoid prosecution for a state felony. 18 U.S.C. $\$ 1073$ (1982).

144 No culpability is required for the underlying offense, however, where it is a strict liability crime. 
circumstances. A C.I.A. agent may provoke an attack to conceal, under the guise of self-defense, a homicide justified by a spy's imminent attempt to leave the country with information that will lead to nuclear war. The agent would be entitled to a justification defense for creating the circumstances justifying the homicide.

Similarly, an actor may have a justification defense for his conduct in creating excusing conditions. A C.I.A. agent who is squeamish about carrying out an order to execute an enemy spy may go to a hypnotist to be given a hypnotic suggestion to carry out the lawful order. One may also be excused for creating excusing conditions. If unknown to the agent the order to kill the spy was unlawful, the agent would be excused for his conduct in culpably creating his state of hypnosis. His excuse would be his reasonable mistake as to a justification for creating the exculpatory state of hypnosis.

Current law generally fails to provide any defense where it imposes liability on an actor who causes the conditions of his defense. One area that has received attention, however, is that of voluntary intoxication and its effect on the availability of both the general excuse and the failure of proof defense for intoxication.

\section{1. "Involuntary" Intoxication}

Whether an actor has a defense for causing his own exculpatory intoxication is, in effect, the issue in determining what will constitute "involuntary" or "not self-induced" intoxication. ${ }^{145}$ The Model Penal Code uses the term "self-induced" intoxication, rather than "voluntary" intoxication, and defines that term to mean "intoxication caused by substances which the actor knowingly introduces into his body, the tendency of which to cause intoxication he knows or ought to know ...."148 Apparently, the

16s See generally J. Hall, General Principles of Criminal Law 538 (2d ed. 1960) ("The initial difficulty of ascertaining the meaning of 'voluntary' intoxication results from the failure of the courts to define the term. . . The chief judicial method of elucidating the meaning of 'voluntary' has been by way of generalizing the exceptions from liability. . . .").

Under the Model Penal Code, the general intoxication excuse is available only for "not self-induced" and "pathological" intoxication. Model Penal Code $\$ 2.08(1)$, (4) (Proposed Official Draft 1962). In failure of proof cases, the defendant will have recklessness imputed to him if his intoxication is "self-induced." Id. $\$ 2.08(2)$; see supra notes $45-51$ and accompanying text.

${ }^{148}$ Model Penal Code $\$ 2.08(5)$ (b) (Proposed Official Draft 1962). 
actor must know that he is introducing the substance but need only be negligent as to its intoxicating effect.

To the extent that the Code incorporates the common-law doctrine that intoxication caused by another's fraud or artifice is involuntary, ${ }^{147}$ it perhaps recognizes what is essentially a failure of proof defense to culpable intoxication. The Code permits a similar failure of proof defense when it incorporates in the definition of "self-induced" a provision that intoxication is not self-induced if the intoxicating substance was taken "pursuant to medical advice."148

Under the Code, an actor also may offer a justification or excuse defense to a charge that the actor was culpable as to his intoxication. Intoxication is not self-induced if the actor introduced the substance into his body "under such circumstances as would afford a defense to a charge of crime." "T⿱4⿴囗十 The "medical advice" exception

For an additional Model Penal Code definition designed to distinguish voluntary and involuntary intoxication, see infra note 151 and accompanying text. The Model Penal Code defines "intoxication" to mean "a disturbance of mental or physical capacities resulting from the introduction of substances into the body." Id. $\S 2.08(5)$ (a).

${ }_{147}$ The comment to the definition of self-induced intoxication notes: "Of course, intoxication caused by the fraud of another is not self-induced." Model Penal Code $\S 2.08$ comment 6 (Tent. Draft No. 9, 1959). A qualification to this statement should be that the actor must not have been negligent in being fraudulently induced to consume the substance. Unfortunately, the cases, like the Code's draftsmen, do not distinguish the two victims of trickery. See cases cited infra note 149.

1*A Model Penal Code $\$ 2.08(5)$ (b) (Proposed Official Draft 1962). Like the "fraud or artifice" concept, medical advice acts as a failure of proof defense only if the patient should not have known of the substance's intoxicating effects. For another explanation of the medical advice exception, see infra text accompanying note 150 .

14 Model Penal Code $\$ 2.08(5)($ b) (Proposed Official Draft 1962). "The draft, by its definition of intoxication which is not self-induced, would give a defense if the intoxication results from such duress as would afford a defense to a charge of crime." Model Penal Code $\S 2.08$ comment 6 (Tent. Draft No. 9, 1959). Cases and other statutes, however, do not distinguish the failure of proof explanation given in the text's preceding paragraph from the excuse or justification explanation in this paragraph, and usually refer generally to "force or fraud," often in dicta. Furthermore, as with the victim of a fraud or trick, see supra note 147 , there is no attempt to determine whether the actor was culpable as to being coerced into taking the substance. See, e.g., Miller v. State, 439 So. 2d 800, 802 (Alg. Crim. App. 1983) (involuntary intoxication results from force, fraud, or artifice); Easter v. District of Columbia, 209 A.2d 625, 627 (D.C. 1965) (involuntary intoxication is without consent, or through force or fraud, but cannot be caused by chronic alcoholism), modified, 361 F.2d 50 (D.C. Cir. 1966) (in cases of public intoxication, chronic alcoholism constitutes involuntary intoxication; relying on alternative statutory, common law, and constitutional grounds); People v. Walker, 33 Ill. App. 3d 681, 688, 338 N.E.2d 449, 454 (1975) (involuntary intoxication is by trick, artifice, or force); State v. Collins, 305 N.W.2d 434 (Iowa 1981) (involuntary 


\section{may also operate as a specific category of justification defense to} the extent that it envisions an actor who did know of a substance's intoxicating effects, but consumed it anyway in reliance on his doctor's advice to avert greater injury to himself. ${ }^{150}$

The Model Penal Code also defines a condition, "pathological

intoxication may be caused by force, fraud, or contrivance; applying a statute); Commonwealth v. Sheehan, 5 Mass. App. Ct. 754, 759 n.4, 370 N.E.2d 1021, 1024 n.4 (1977) (involuntary intoxication results from forced consumption or secret administration of intoxicants), aff'd on other grounds, 376 Mass. 765, 383 N.E.2d 1115 (1978); City of Minneapolis v. Altimus, 306 Minn. 462, 468, 238 N.W.2d 851, 856 (1976) (involuntary intoxication may result from coercion); State v. Bishop, 632 S.W.2d 255, 258-59 (Mo. 1982) (involuntary intoxication may be caused where the intoxicant is forcibly administered or unwittingly ingested through physical compulsion, trickery, deception, or other external force); State v. Plummer, 117 N.H. 320, 326, 374 A.2d 431, 435 (1977) (involuntary intoxication may be a product of fraud, force, or coercion); People v. Carlo, 46 A.D.2d 764, 764, 361 N.Y.S.2d 168, 169-70 (1974) (fraud may produce involuntary intoxication); State v. Bunn, 283 N.C. 444, 457, 196 S.E.2d 777,786 (1973) (involuntary intoxication may be intoxication induced by force or coercion); Jones v. State, 648 P.2d 1251, 1258 (Okla. Crim. App. 1982) (involuntary intoxication may be caused by fraud, trickery, or duress), cert. denied, 459 U.S. 1155 (1983); Burns v. State, 591 S.W.2d 780, 783 (Tenn. Crim. App. 1979) (involuntary intoxication may be caused by fraud or duress); Loveday v. State, 74 Wis. 2d 503, 511-12, 247 N.W.2d 116, 122 (1976) (involuntary intoxication may be induced by force or fraud).

The "defense" language of the Model Penal Code section may be too broad, moreover, in that it seems to render the intoxication involuntary whenever the defendant would have any defense to any offense. For example, just because the circumstances of the drinking would give the defendant a defense to "drinking in public"-i.e., the drinking was done lawfully, in that sense, by being done in private--this does not mean that it should be considered involuntary intoxication.

${ }^{150}$ As with the "force or fraud" cases, there is apparently no coherent view as to whether medical advice acts as proof of nonnegligence as to the substance's effects or as proof of a justification for taking an acknowledged risk. Compare Perkins v. United States, 228 F. 408, 415-16 (4th Cir. 1915) (warnings printed on prescription and actor's experience with the drug are relevant to the issue of voluntariness); Burnett v. Commonwealth, 284 S.W.2d 654, 658-59 (Ky. 1955) (actor who neither knew of nor had reason to foresee prescription drug's intoxicating effect cannot be guilty of a negligence offense); and City of Minneapolis v. Altimus, 306 Minn. 462, 469-71, 238 N.W.2d 851, 856-57 (1976) (actor who neither knew nor had reason to know of prescription drug's intoxicating effect may claim insanity defense); with Johnson v. Commonwealth, 135 Va. 524, 534-35, 115 S.E. 673, 677 (1923) (intoxication is voluntary if actor drinks whiskey to relieve pain but does not do so pursuant to medical advice; the court implied, therefore, that had the whiskey heen taken upon advice, the intoxication might be involuntary).

Other cases are ambiguous. See, e.g., Saldiveri v. State, 217 Md. 412, 425, 143 A.2d 70, 77 (1958) (intoxication caused by unskilled administration of a drug by a physician ordinarily constitutes a defense) (dictum); State v. Plummer, 117 N.H. 320, 326, 374 A.2d 431, 435 (1977) (involuntary intoxication may result where substances are ingested pursuant to medical prescription); Jones v. State, 648 P.2d 1251, 1258 (Okla. Crim. App. 1982) (ignorance of the effects of prescribed medication may result in involuntary intoxication), cert. denied, 459 U.S. 1155 (1983). 
intoxication," that provides an additional means of establishing involuntary intoxication. It permits the intoxication to be deemed involuntary where it is "grossly excessive in degree, given the amount of the intoxicant, to which the actor does not know he is susceptible." 151 Thus, the actor's intoxication is pathological if the actor does not know his susceptibility to the intoxicant. ${ }^{152}$ Even if one accepted the Code's decision to equate culpability as to intoxication with culpability as to the offense, however, this provision might be as improperly lenient as the "self-induced" provision is improperly harsh. An actor may be reckless but not "know" that he is susceptible to an abnormally high intoxicating effect from a substance, yet may successfully use this "pathological" intoxication to negate the recklessness needed for manslaughter (reckless homicide). ${ }^{153}$

${ }^{181}$ Model Penal Code $§ 2.08(5)$ (c) (Proposed Official Draft 1962); accord N.J. Stat. Ann. $\S 2 \mathrm{C}: 2-8(\mathrm{e})(3)$ (West Supp. 1984-1985) (Model Penal Code formulation); cf. Hawaii Rev. Stat. $\S 702-230(3)$ (c) (1976) (adds to the Model Penal Code formulation a requirement that the pathological intoxication must result from a physical abnormality of the defendant). Some would argue that such pathological intoxication defenses are inadequate to deal with drug intoxication; the argument considers research indicating that drugs, unlike alcohol, produce unpredictable results and, in effect, the drug "tricks" the defendant. See Special Project, Drugs and Criminal Responsibility, 33 Vand. L. Rev. 1145, 1181-82 (1980). This intoxication would not be "pathological" because the actor anticipates intoxication, but it may be nonculpable because the actor does not anticipate the effect of the intoxicant.

${ }_{152}$ This provision "is designed to provide a defense in a few, extremely rare, cases in which an intoxicating substance is knowingly taken into the body and, because of a bodily abnormality, intoxication of an extreme and unusual degree resuits." Model Penal Code $\S 2.08$ comment 7 , at 11 (Tent. Draft No. 9, 1959). There is some authority for such a basis for "involuntary" intoxication. See, e.g., Leggett v. State, 21 Tex. Crim. 382, 398-99, 17 S.W. 159, 161 (1886) (defendant given defense where he drank liquor insufficient to cause intoxication and later received a blow to the head that caused the liquor to produce gross intoxication).

${ }^{153}$ It appears that an actor may introduce evidence of pathological intoxication to negate any offense element. The Model Penal Code provides that "intoxication . . . is not a defense unless it negatives an element of the offense." Model Penal Code $\$ 2.08(1)$ (Proposed Official Draft 1962). For similar statutes in other jurisdictions, see supra note 45 and accompanying text. By implication, intoxication is a defense under such provisions if it does negate an element. Model Penal Code $\$ 2.08(2)$ then prohibits intoxication from negating recklessness when the intoxication is "self-induced." It provides no such bar to "pathological" intoxication; thus presumably, like other forms of involuntary intoxication, pathological intoxication is permitted to negate any culpability requirement, including recklessness.

One could argue that all cases of pathological intoxication are, by definition, cases of seifinduced intoxication. Indeed, the definitions of "pathological" and "self-induced" intoxication seem to compel such an interpretation. An actor who becomes grossly intoxicated upon drinking two cans of beer after a three day fast and who does not know that he will be susceptible to such gross intoxication under such circumstances may be pathologically intox- 


\section{The Problem of Alcoholism and Drug Addiction}

Alcoholism (or alcohol addiction, as it may properly be called) may be a defense to causing one's own intoxication, but it presents special problems that illustrate the potential complexities in evaluating defenses to liability for causing one's own defense. If it could be shown that the physiologically addicted actor's compulsion to take drugs is as overpowering as the compulsions sufficient to excuse under either the insanity or duress defenses, ${ }^{154}$ the compulsion might be sufficient to establish that the addict's intoxication is involuntary. ${ }^{155}$ When the addiction is purely psychological, however, it may be more difficult to determine the strength of the compulsion. ${ }^{15 \theta}$

icated. Id. $\S 2.08(5)(c)$, quoted supra in text accompanying note 151; see also Model Penal Code $\$ 2.08$ comment 7 (Tent. Draft No. 9, 1959) (giving a similar hypothetical as an example of pathological intoxication). It would also seem, however, that the actor's intoxication is "self-induced." He "knowingly introduce[d]" a substance-beer-"the tendency of which to cause intoxication" he "ought to [have known]." Model Penal Code $\S 2.08(5)$ (b) (Proposed Official Draft 1962), quoted supra text accompanying note 146.

Under this view, $\S 2.08(2)$ would be read to bar pathological intoxication from negating recklessness, just as self-induced intoxication is barred. On the other hand, one could argue that because the drafters have carefully distinguished and separately defined self-induced intoxication and pathological intoxication, by expressly limiting $\$ 2.08(2)$ only to cases of the former, they meant to exclude cases of the latter from the operation of that section. In other words, pathological intoxication would be permitted to negate recklessness. There seems little theoretical justification, however, not to accord both forms of involuntary intoxication similar effect. Thus, the interpretation adopted in the text should be preferred.

The rationales supporting a limitation of the failure of proof defense for one who has, in the ordinary sense of the word, induced his intoxication do not support such a limitation for one who is pathologically intoxicated. The pathologically intoxicated actor neither risked becoming and acting drunk nor demonstrated moral culpability by engaging in conduct known to destroy the powers of perception and judgment. See Model Penal Code $\S 2.08$ comment 3, at 9 (Tent. Draft No. 9, 1959) (actor who induces his intoxication does take such risks and demonstrate such culpability). One might well question the rationales for denying the defense even to the actor whose intoxication was truly self-induced. See supra text accompanying notes 49-50.

Is See Lowenstein, Addiction, Insanity, and Due Process of Law: An Examination of the Capacity Defense, 3 Harv. C.R.-C.L. L. Rev. 125, 146-47 (1967); Special Project, supra note 151 , at 1198-99.

1ss See generally W. LaFave \& A. Scott, supra note 20, at 350 (comparing alcohol versus narcotics addiction in establishing involuntariness); Special Project, supra note 151, at 1183 . 84 (discussing intoxication and involuntariness).

146 Bowman, Narcotic Addiction and Criminal Responsibility Under Durham, 53 Geo. L.J. 1017, 1036-37 (1965), argues that in psychologically-induced addiction, the addict's underlying psychological disorder leads him, but not the normal person, to relieve his anxiety through the drug. The degree of dependence, therefore, varies with the individual's underlying disorder. 
The dispute over the significance of addiction for criminal liability arises from disagreements not only over the effects of addiction, but also over the actor's ability to control the process of addiction. Once it is possible to speak cogently of an actor's control over becoming addicted, the causing-one's-defense analysis proposed above becomes appropriate in determining whether an addict merits an excuse either for his offense conduct or for his conduct in causing the conditions of his intoxication defense. Society may withhold a defense based on addiction where the addiction was voluntary and provide the defense only when the addiction was involuntary.

There are three distinct difficulties with this line of analysis. First, although the terms "voluntary" and "involuntary," as applied both to addiction and intoxication, are time-honored components of the standard vocabulary, they are inexact substitutes for the concept of culpability. Second, the issue of whether a particular person is voluntarily (or culpably) addicted is complex. There are clearly cases of addiction that the actor has no part in creating. ${ }^{157}$ More often, an actor who intentionally takes drugs may be only reckless or negligent as to becoming addicted; rarely does an actor intend to become addicted. ${ }^{158}$ This difficulty in ascertaining an actor's culpability as to becoming addicted raises many of the problems discussed above with regard to the definition of "voluntary" intoxication ${ }^{159}$ and with regard to differing levels of culpability in causing one's own excusing conditions. ${ }^{180}$ Another complicating factor is the actor's reduced capacity to foresee the ultimate addictive effect once he has taken the first drink, pill, or injection. ${ }^{161}$

167 For example, addiction may be caused by medical treatment. See Bowman, supra note 156, at 1030. The number of such addictions, however, seems to be minimal. See id; Fingarette, Addiction and Criminal Responsibility, 84 Yale L.J. 413, 428 (1975).

138 One author posits that the use of narcotics does not "even usually" lead to addiction. See Bowman, supra note 156 , at 1036 . He argues that it is the individual's pre-existing psy. chological defects that cause his reaction to the drug to lead to addiction. Id. Contra Fingarette, supra note 157, at 431-33 (arguing that social factors cause most addiction).

${ }^{180}$ One problem is the difficulty in formulating a definition of voluntary that properly distinguishes culpable and nonculpable intoxication. See supra notes 145, 149-50; see generally Special Project, supra note 151, at 1181-83 (discussing the unpredictable nature of drug intoxication).

${ }^{180}$ See supra text accompanying notes 31-32, 45-51 (discussing the impropriety of barring a defense on the basis of negligence where the offense requires higher culpability).

18) See Bowrnan, supra note 156, at 1036 (for the addiction-prone person, the first experi- 
The issue is complicated still further by evidence that some are more addiction-prone than others. ${ }^{16 \%}$ Une's existing genetic and psvchological state may arguahly combine with envirnnmental factors to create a tendency toward addiction. Ascertaining the addiction's original cause, which may have occurred years before the addiction, is notably more complicated and more speculative than determining whether an actor's intoxication was voluntary (or culpable).

Perhaps most important, the inquiry into the voluntariness of an actor's addiction is indeterminative. The critical issue is not the actor's culpability as to creating the conditions of his excuse-whether the excuse be intoxication or addiction - but rather is the actor's culpability as to subsequently committing the excused criminal offense. ${ }^{103}$.

When addiction is used as the excuse, the complexities of determining the voluntariness of the addiction may render truly speculative the inquiry into the actor's culpable state of mind at the time of creating the addiction as to the commission of that subsequent substantive offense. The inquiry, however, is not impossible. As a starting point, one might assume that a person who knowingly becomes addicted is at least aware of a risk that the addiction may result in a compulsion to steal or possess illegal drugs.

When addiction is raised as a defense to causing one's own excusing conditions, however, the opposite assumption might be drawn. It seems entirely unlikely that the actor, at the time of causing the addiction, would have had any culpable state of mind as to the ultimate offense that was to be excused by the addictioninduced intoxication. The actor would have to have been aware at the first instance that his consumption would eventually cause addiction, that would in turn cause subsequent involuntary intoxication, that would in turn cause him to misperceive the nature of his conduct, misunderstand the legal rules governing his conduct, or lose control of his conduct, and thereby commit the criminal of-

ence with intoxicants is more than just pleasurable; he develops a psychological craving that he probably cannot ignore, and addiction is virtually inevitable for him).

162 See Bowman, supra note 156, at 1029-39.

${ }^{103}$ See supra section II(C). If an actor becomes grossly intoxicated with the purpose of then killing his wife, he is appropriately convicted of murder; if he becomes intoxicated while aware of a substantial risk that he will beat his wife while drunk, manslaughter (reckless homicide) is more appropriate. 
fense. Given the unlikelihood of such a culpable state of mind, an actor who raises addiction as a defense to causing his own excusing conditions (as in involuntary intoxication), especially if he was addiction-prone, ${ }^{104}$ should be able to maintain his intoxication defense. This only means, however, that his intoxication is to be viewed as "involuntary." To escape liability he must still satisfy the requirements of the defense. He must establish, for example, that the effect of his involuntary intoxication on this occasion satisfies the cognitive or control dysfunctions of the general involuntary intoxication excuse. ${ }^{185}$

\section{Problems, Solutions, and Compromises in Translating Theory into Workable Doctrine}

\section{A. Translating Theory into Doctrine}

The causing-one's-defense analysis proposed in Part II can be translated into clear doctrine through the following provisions:

\section{Causing the Conditions of One's Own General Defense}

(1) Causing Justifying Circumstances or Excusing Conditions No Bar to Defense. The fact that an actor has caused the circumstances giving rise to the need for his justified conduct or that an actor has caused the conditions giving rise to his excuse shall not itself bar the justification or excuse defense for the actor.

(2) Liability for Causing Justifying Circumstances or Excusing Conditions. An actor is guilty of an offense when acting with the culpability required by the offense definition he causes the circumstances that justify his [or another's] ${ }^{180}$ engaging in the conduct that constitutes the offense or causes the conditions that excuse himself [or another] for engaging in the conduct that constitutes the offense, and he [or such other person] engages in the conduct constituting the offense.

(3) Defenses to Liability for Causing Conditions of One's Defense.

164 See supra notes 161-62 and accompanying text.

165 A few state supreme courts have held, however, that an alcoholic's intoxication is voluntary. See, e.g., Evans v. State, 645 P.2d 155, 160 (Alaska 1982); State v. Johnson, 327 N.W.2d 580 (Minn. 1982); Loveday v. State, 74 Wis. 2d 503, 513-16, 247 N.W.2d 116, 122-24 (1976).

${ }^{188}$ The bracketed language would be needed only if the code did not contain a provision imposing liability for causing crime by an innocent, such as Model Penal Code $\$ 2.06(2)$ (a) (Proposed Official Draft 1962). For a discussion of this provision and its overlap with causing the conditions of one's own defense, see supra notes 116, 121. 
An actor may have a justification or excuse defense to liability under subsection (2) for his conduct in causing the conditions of his exculpation.

Similarly, the theory developed in Part II suggests a doctrine to govern "failure of proof" defenses. Intoxication negating an offense element is the most common such defense raising causing-one'sdefense issues:

\section{Intoxication Negating an Offense Element}

(1) Evidence of intoxication, voluntary or involuntary, may be admitted into evidence to negate a culpability element of an offense. (2) If an actor's intoxication negates a required culpability element at the time of the offense, such element is nonetheless established if the actor satisfied such element immediately preceding or during the time that he was becoming intoxicated or at any time thereafter until commission of the offense, and the harm or evil he intended, contemplated, or risked is brought about by the actor's subsequent conduct during intoxication.

(3) An actor may have a justification or excuse defense to liability under subsection (2) for his conduct in causing the conditions of his exculpation.

Thus, the translation from theory to doctrine is relatively easy. Difficulties arise, however, not in making the translation, but in guaranteeing the feasibility or workability of the resulting doctrine.

\section{B. Complexity Problems}

The provisions implementing the proposed causing-one's-defense analysis can be complex. The complexity raises two questions. Can jurors reasonably be expected to understand and apply the doctrine? Can complex doctrine serve the deterrent functions of the criminal law?

\section{The Jury}

One objection to any attempt at a refined solution to the causing-one's-defense problem is the claim that these solutions commonly require jury instructions of such complexity that the jury cannot reasonably be expected to understand and apply them. ${ }^{167}$

${ }^{107}$ For example, in rejecting the proposal of Professors Smith and Williams that would 
One response is that instructions under these rules are within the range of complexity currently tolerated; many existing instructions are extremely complex. ${ }^{168}$ On the other hand, the doctrine may require somewhat more complicated and more numerous determinations than do many current issues. For example, the jury must evaluate the actor's conduct and state of mind not only at the time of the conduct constituting the offense, but also at the time he brought about the defense conditions. The latter determination is especially complicated because the jury must evaluate the actor's state of mind at a past time-when he caused the defense conditions--with respect to the then future ultimate offense. Furthermore, in some cases, the jury would also be required to decide whether the actor had an excuse or a justification defense at the time he brought about the defense conditions. The complexity is undeniable. The issue, however, is whether the additional complexity will prevent jurors from understanding the doctrine or, even if they understand the doctrine, from applying it.

Recent studies demonstrate that jurors have a poor understanding of traditional jury instructions. ${ }^{16 \theta}$ Research also indicates, how-

have addressed cases of voluntary intoxication negating an element, discussed infra text accompanying note 198, the Criminal Law Revision Committee noted that the Smith-Williams resolution "would add to the already considerable number of matters which a jury often has to consider . . . [making] the jury's task even more difficult than it is at present

" Criminal Law Revision Committee, Fourteenth Report: Offences Against the Person, Cmnd. $7844, \uparrow 264$, at 114 (1980). The Committee also noted that the inquriy would create another issue on which the jury might disagree. Id.

${ }^{168}$ See, e.g., E. Devitt \& C. Blackmar, Federal Jury Practice and Instructions $\S \S 27.04-.05$ (3d ed. 1977), for model instruction on conspiracy. The instruction requires nine paragraphs describing respectively the "gist of the offense," what kind of association is inadequate, what the evidence must show and what it need not show with respect to agreement, what the evidence need not and must show with respect to the plan, what is and is not adequate knowledge of the plan and the participation required, the meaning of willful participation, the responsibility of one who joins an ongoing conspiracy, and the law governing the use of evidence of acts and declarations of co-conspirators. See also Schwarzer, Communicating with Juries: Problems and Remedies, 69 Calif. L. Rev. 731, 745.46 \& n.71 (1981) (quoting, criticizing, and reformulating the Devitt and Blackmar model instruction).

${ }^{189}$ One study showed that individual jurors comprehended only $53.1 \%$ of the instructions that they received, and jurors who combined efforts reached a comprehension level of $63.3 \%$. Furthermore, $83 \%$ of criminal jurors could not respond accurately to the question "what is proof of guilt?" Forston, Sense and Non-Sense: Jury Trial Communication, 1975 B.Y.U. L. Rev, 601, 614-15.

Other studies indicate that jurors cannot select correct definitions of legal terms as fundamental to their duties as "preponderance of the evidence," "burden of proof," "impeach," and "inference"; over one-half of the jurors in one study selected "a slow and careful 
ever, that the complexity of the legal concept being conveyed is not a primary reason for the jury's compreliension problenins. ${ }^{170} \mathrm{Re}-$ searchers and commentators instead identify the following contributing factors: the practice of delivering instructions after the evidence is received, ${ }^{171}$ the practice of delivering only verbal instructions, ${ }^{172}$ the use of legal jargon, ${ }^{173}$ the length of the instructions (in particular, the tendency to incorporate detailed statements of the law with refined qualifications and exceptions, rather than broad understandable statements of principle), ${ }^{174}$ illogical organization of the instructions, ${ }^{175}$ and a reliance on abstract legal statements rather than a focus on the specific factual inquiries ne-

pondering of the evidence" as the correct meaning for "preponderance of the evidence." Schwarzer, supra note 168, at 741. In a test of Florida's model jury charges, only $50 \%$ of the jurors understood that the defendant was not required to produce evidence of his innocence. Strawn \& Buchanan, Jury Confusion: A Threat to Justice, 59 Judicature 478, 480-81 (1976); see also Elwork, Sales \& Alfini, Juridic Decisions: In Ignorance of the Law or in Light of It?, 1 Law \& Hum. Behav, 163, 175-76 (1977) (presentation of pattern instructions to the jury was no more effective than not presenting instructions at all); see generally Charrow \& Charrow, Making Legal Language Understandable: A Psycholinguistic Study of Jury Instructions, 79 Colum. L. Rev. 1306, 1308 n.8 (1979) (listing published studies on juror comprehension).

${ }^{370}$ In one study, attorneys were requested to evaluate the difficulty of the legal concepts conveyed in particular jury instructions. Assuming the accuracy of the attorney evaluations, the research revealed that conceptual complexity plays a secondary role in the comprehensibility of jury instructions. Charow \& Charrow, supra note 169, at 1334-35.

${ }^{171}$ See Avakian, Let's Learn to Instruct the Jury . . . Before the Trial, During the Trial and Before Final Argument, Judges' J. Summer 1979, at 40, 42-43; Forston, supra note 169, at 620-23; Prettyman; Jury Instructions-First or Last?, 46 A.B.A. J. 1066, 1066 (1960); Winslow, The Instruction Ritual, 13 Hastings L.J. 456, $469-71$ (1962); Comment, Memory, Magic, and Myth: The Timing of Jury Instructions, 59 Or. L. Rev. 451, 453-56 (1981).

${ }_{172}$ See Forston, supra note 169, at 619-20; Joiner, From the Bench, in The Jury System in America: A Critical Overview 151 (R. Simon ed. 1975) (stating a preference for both oral and written instructions, and describing jurors' use of written instructions); Schwarzer, supra note 168, at 756-57 (advocating written instructions).

${ }^{173}$ See Charrow \& Charrow, supra note 169, at 1321-28, 1358-60; Forston, supra note 169, at 616-18; Schwarzer, supra note 168, at 740-43; Winslow, supra note 171, at 459-60.

174 See Joiner, supra note 172, at 150-51 (arguing for understandable statements of principle and not detail, indicating that qualifications and exceptions cannot be absorbed and applied by the rank and file). Schwarzer argues that listeners have a limited ability to assimilate, and that the process of listening requires them to select and exclude information. The selection process, one of overgeneralization, may cause the jury to acquire ideas different than those the speaker intended to convey. Schwarzer, supra note 168 , at $741-42$. For a comparison of instructions based on statements of general principles of negligence with in. structions composed of lengthy expositions on negligence, contributory negligence and proximate cause, see Winslow, supra note 171, at 460-69.

${ }_{175}$ See R. McBride, The Art of Instructing the Jury $\S 5.03$, at 183 (1969); Forston, supra note 169 , at 619 . 
cessitated by the evidence. ${ }^{176}$

The causing-one's-defense doctrine suggested here would not implicate the factors that foster jury confusion. Several of these factors-the timing and manner of delivery, the simplicity of language, and the logical ordering of the instructions-are unrelated to the conceptual content of the instructions. For the remaining factors, the proposed causing-one's-defense doctrine, although complex, does not rely on abstract legal statements or on detailed or refined qualifications and exceptions to the law.

Indeed, in light of this research on juror comprehension, the proposed causing-one's-defense doctrine may well foster juror understanding. Unlike artificial legal abstractions that are designed to further unstated public policies, the doctrine does not consist of a host of apparently meaningless and unprincipled rules and exceptions. ${ }^{177}$ Instead, it is a theory of liability based on a general principle easily stated in ordinary language: If the actor caused the conditions of his defense and at the time he caused those conditions he had the culpable state of mind required by the offense, he is guilty of the offense. In other words, after the jury is instructed as to the state of mind requirements of the underlying offense, they may be instructed that "the defendant may satisfy these elements either at the time of the offense or at the time he causes the conditions of a defense."

Furthermore, the general principles of liability and exculpation that inform the proposed doctrine comport with our collective sense of justice. They recognize that blameworthiness is critical to

176 As one author has noted, studies showing that prior knowledge of or exposure to a situation is a significant element of comprehension "provide a powerful argument against the use of abstract statements of legal principles and for the use of instructions phrased as concrete statements of the questions to be decided, incorporating the evidentiary context of persons, places, things, and events disclosed at trial." Schwarzer, supra note 168, at 741; see generally Winslow, supra note 171 , at $469-73$ (arguing that jury instructions should be individually tailored to each case). For a discussion of "process" instructions designed to permit jurors to decide legal questions raised by the case in a logical order dictated by the law and evidence, see Taylor, Buchanan, Pryor \& Strawn, Avoiding the Legal Tower of Babel: A Case Study of Innovative Jury Instruction, Judges' J., Summer 1980, at 10.

${ }^{177}$ Existing law is often stated in terms of these rules and exceptions. See, e.g., Model Penal Code $\$ 3.06$ (Proposed Official Draft 1962) (defining the law of defense of property governing recapture and reentry in terms of numerous exceptions and qualifications to the general principle); see Model Penal Code $\$ 3.06$ comment 14 (Tent. Draft No. 8, 1958) (suggesting that the limitations and exceptions are designed, in part, to require certain victims of property aggression to seek relief in the courts). 
both the assignment and degree of criminal liability. Thus, the causing-one's-defense doctrine, while requiring the jury to make complex factual findings, does not require the jury to understand and apply abstract or artificial rules or exceptions to general principles. Rather, the doctrine is a logical extension of general principles of criminal liability.

To illustrate the practical benefit of a doctrine that mirrors general principles of justice, compare the explanations required to implement the rules on intoxication negating an offense element, as adopted in the Model Penal Code, with those required by the proposed causing-one's-defense doctrine. Model Penal Code $\S 2.08$ requires an instruction on the definition of "self-induced intoxication." ${ }^{178}$ This legal definition is extremely abstract, requiring an instruction explaining that intoxication that is not self-induced may negate any offense element ${ }^{179}$ and an explanation that intoxication that is self-induced may negate purpose or knowledge but may not negate recklessness. ${ }^{180}$ Correct verdicts depend on the jurors' ability to comprehend, recall, and apply these abstract rules and exceptions. The complexity will be multiplied where one offense requires a variety of mental states. ${ }^{181}$ The Model Penal Code rules appear to be as artificial as they are complicated; the jurors are told that one kind of intoxication may negate any mental element and that another may not. Clearly, the reason must appear to the jurors to be the artificial rule and not some difference between the two kinds of intoxication and their relevance to proving the actor's state of mind. ${ }^{182}$

${ }_{178}$ Model Penal Code $\S 2.08(5)(b)$ (Proposed Official Draft 1962).

178 Id. $\S 2.08(1)$.

180 Id. § 2.08(2).

${ }^{181}$ For example, robbery requires proof of a theft or attempted theft, both of which require purpose. See, e.g., id. $\$ 5.01$ ("Criminal Attempt"); id. $\$ 221.1$ ("Robbery"); id. $\S 223.2$ ("Theft by Unlawful Taking or Disposition"). One form of robbery requires proof of the infliction of serious bodily harm, an element as to which the actor must only be reckless. See, e.g., id. $\S \S 2.02(3), 222.1(1)(a)$.

${ }^{162}$ Here, the artificial rule is based on a pastulated equivalence of the risk an actor takes in becoming drunk and the risk created by his drunken conduct. Model Penal Code $\S 2.08$ comment 3, at 8-9 (Tent. Draft No. 9, 1959). The rule is also designed to compensate for difficulties of proof. Id.

There can be no question, however, that where there is no relationship between what the actor risks in becoming drunk and the harm he causes, the rule distorts the general principle that requires culpability as to the objective elements of the offense. Thus, the jury is presented with conflicting rules: one requires proof of culpability, and one dispenses with 
In contrast, the causing-one's-defense doctrine requires a single explanation. If the actor had the required mental state either at the time he committed the offense or at the time he caused his intoxication, he is guilty of the offense. There is nothing complex or artificial in the application of the principle. It is both comprehensible and simple.

In addition to its simplicity, the causing-one's-defense doctrine provides something that other researchers view as a necessary remedy to jury misunderstanding: instructions that present questions in a logical sequence related to the evidence presented. ${ }^{183}$ The causing-one's-defense doctrine requires instructions that compel specific chronologically ordered factual findings, and thus, if researchers are correct, its use may increase juror comprehension.

\section{General Deterrence}

The proposed causing-one's-defense doctrine may also be criticized as being too complex to adequately serve the criminal law's goal of general deterrence. Complex doctrines in criminal law have been criticized because the law cannot deter potential offenders from engaging in prohibited conduct if the rules of liability are too complex for people to understand. ${ }^{184}$ As was the case with complexity in jury instructions, however, complexity is less detrimental if it derives from consistent application of general principles of liability and exculpation that are consistent with a collective sense of justice.

Consistent application of such general principles might even en-

the requirement. It is interesting to note that a classic study on jury performance revealed that jurors often either did not understand or chose to ignore instructions that precluded them from considering intoxication as a defense to certain crimes. See H. Kalven, Jr. \& H. Zeisel, The American Jury 334-38 (1966).

${ }_{183}$ Taylor, Buchanan, Pryor \& Strawn, supra note 176, discuss problem solving in a small group, and stress the benefit of step-by-step patterns for such a group. Research on the significance of "goal clarity" and "goal path clarity" led to the development of "process" or step-by-step instructions for. a Florida criminal trial. See also Joiner, supra note 172 (stating preference for use of particularized questions detailing issues that the jury must resolve to reach a verdict).

${ }^{164}$ To Livingston, who stressed the importance of utility, the "legitimacy of the law depended upon its being readily knowable and known." Kadish, Codifiers of the Criminal Law: Wechsler's Predecessors, 78 Colum L. Rev. 1098, 1100-02 (1978) (noting that Livingston strove to make the law plain, unequivocal, and understandable); see also Joiner, supra note 172, at 150-51 (equating the need for understandable statements of principles of law both in jury instructions and in laws regulating behavior). 
hance public understanding of and adherence to the criminal law. Tó recognize general excuses that exculpate the blameless, for ex. ample, demonstrates that the law is just, and thereby encourages compliance and lends credibility to its condemnatory function. ${ }^{185}$ Similarly, because the causing-one's-defense doctrine comports with the general culpability principle and assures a defense when and only when an actor is sufficiently blameless-rather than when certain arbitrary and artificial rules are satisfied ${ }^{\mathbf{1 8 a}}$ - the doctrine fosters both general understanding of and compliance with the law. If general principles consistent with our collective sense of justice shape a doctrine, the doctrine will likely be understood and viewed as just. In essence, doctrines that comport with our collective sense of justice are as essential to a system of criminal law based on deterrence $^{187}$ as they are to one based on blameworthiness and just deserts. ${ }^{188}$

\section{Difficulties of Proof}

A different type of objection to the causing-one's-defense provisions set out above is that they require the proof of culpable states of mind that would, in practice, be difficult to prove. ${ }^{\mathbf{1 8 \theta}}$ As noted,

196 See Kadish, The Decline of Innocence, 26 Cambridge L.J. 273, 282-83, $287-88$ (1968); see also P. Brett, An Inquiry Into Criminal Guilt (1963) (arguing that society's system of merit and blame demands punishment only of the responsible); A Goldstein, supra note 107, at 16 (arguing that each of the theories underlying criminal law-retribution and rehabilitation-justifies punishment of only those actors who are capable of choosing how they will behave).

${ }^{186}$ As noted previously, by virtue of their artificiality, many rules treating problems of the actor who causes his defense sometimes provide a defense to the blameworthy, see, e.g., supra text accompanying note 40 , and sometimes bar a defense for the actor who is blameless, see supra text accompanying notes 18-22.

${ }^{187}$ Bentham and Livingston recognized that laws contrary to the public opinion should be avoided as they are unenforceable and therefore detrimental to the overall utility of the criminal law. See Kadish, supra note 184, at 1102.

${ }^{188}$ The Model Penal Code is based, in part, on principles of just deserts and culpability. See Model Penal Code $\$ 1.02(1)$ (Proposed Official Draft 1962) (listing among its purposes the prohibition of inexcusable and unjustifiable conduct, the safeguarding of faultless conduct, and the reasonable differentiation between serious and minor offenses). Professor Wechsler, principel architect of the Code, noted that its contents, including its prohibitions and excuses, should be sheped by relating the Code's rules and principles to the fundamental moral assumptions of society. Wechsler, The Model Penal Code and the Codification of American Criminal Law, in Crime, Criminology and Public Policy: Essays in Honor of Sir Leon Radzinowicz 419, 424-25 (R. Hood ed. 1974).

188 The Model Penal Code drafters rejected a proposal that would base liability in the 
the relevant issue is not the actor's culpable state of mind at the time of the conduct constituting the offense, but rather his state of mind as to the offense when he causes the conditions of his defense.

One response to this objection is to note that culpable state of mind elements always present difficult proof problems. The jury is always left to speculate as to the existence of a state of mind that cannot be proven directly but only through circumstantial evidence. Given the inherent difficulty in proving any culpable state of mind, a shift in the time focus may not make the proof problems so much more difficult that they become insurmountable. Yet one cannot deny that proof is more difficult and that this increase is significant. In both cases, the jury must use indirect means to reconstruct the defendant's state of mind at a time long past. The analysis proposed here adds another difficulty, however. In the normal criminal case, the factfinder must determine the actor's past state of mind as to conduct elements of the offense that he was at that moment committing. ${ }^{190}$ The causing-one's-defense inquiry, by contrast, temporally separates the relevant state of mind from the ultimate event or conduct that objectively manifests the criminal offense. The factfinder, therefore, can no longer readily infer from the actor's conduct the actor's state of mind as to that conduct.

\section{Presumptions as a Solution to the Problems of Proof}

Despite the unique obstacles attending a factfinder's application of the causing-one's-defense provisions, a legislature could conclude that they do not entail a significant increase in difficulty over the routine criminal case. Even if the problems of proof are significantly more difficult and even if it is unrealistic to expect the state to prove such culpable state of mind requirements beyond a reasonable doubt, the proposed analysis might remain tenable. To realize the virtues of the proposal, the legislature could in-

case of drunkenness on the actor's state of mind at the time of becoming intoxicated. Model Penal Code $\S 2.08$ comment 3, at 7.8 (Tent. Draft No. 9, 1959). The Advisory Committee noted the "impressive difficulties posed in litigating the foresight of any particular actor at the time when he imbibes." Id. at 9.

${ }^{100}$ For a historical analysis of the evidentiary difficulties in proving past subjective states of mind, see generally Robinson, A Brief History of Distinctions in Criminal Culpability, 31 Hastings L.J. 815, 844-46 (1980). 
clude an evidentiary provision that would make the state's task inure feasible. One such provision would be a rebuttable presumption of culpability that would be triggered by a threshold showing of the defendant's culpability.

Another approach is to require that the state carry only the burden of production on the issue of an actor's culpable state of mind as to the offense at the time he causes his defense. Once the state has produced some evidence, the actor would then have the burden of persuading the jury, by a preponderance of the evidence, that at the time he caused his defense, he lacked the culpable state of mind required by the offense. A similar approach is to maintain the state's burden of persuasion on such an issue but to reduce the standard of proof from proof beyond a reasonable doubt to proof by a preponderance of the evidence. Both approaches, however, are likely to be politically unfeasible because they appear to contradict strongly-held views on the proper allocation and standard of the burden of persuasion.

A somewhat less accurate but possibly more feasible approach would be to modify an existing, accepted doctrine, such as Model Penal Code $\S 2.08(2)$. That section permits voluntary intoxication to negate purpose or knowledge, but imputes recklessness as to the offense elements in all cases where the actor would have been aware of the risk had he been sober. ${ }^{191}$ Section $2.08(2)$ is in essence an irrebutable presumption of recklessness as to the offense elements. The legislature could modify it to make the presumption rebuttable. Accordingly, the defendant would escape or reduce his liability by showing that he was not reckless or negligent as to the offense both at the time he became intoxicated and at the time of the alleged offense. The state could increase the defendant's liability by showing that when he became intoxicated, he was knowing or purposeful as to the offense. ${ }^{102}$

\footnotetext{
${ }^{101}$ Model Penal Code $\S 2.08(1)$, (2) (Proposed Official Draft 1962).

192 Thus, where the state establishes that the defendant committed a homicide and produces evidence that he was at least reckless as to causing his victim's death, the state will normally merit a conviction for reckless homicide. The state could also produce further evidence to show that at the time of the killing, the defendant acted either purposefully or knowingly. If the defendant came forward with evidence of intoxication, the state would be entitled to a presumption that the defendant, who killed in an intoxicated state, was at least reckless as to his victim's death. The defendant would be free to convince the jury that he was neither reckless nor negligent as to causing death at either the time of the homicide or at the time he became intoxicated. The state, on the other hand, would be free to establish
} 
Each of these three approaches reduces the state's burden of persuasion as to one or more elements of the alleged offense, and each therefore may well be unconstitutional. The Supreme Court's decisions in Mullaney v. Wilbur ${ }^{193}$ and Patterson v. New York ${ }^{194}$ may bar such an allocation. The Court requires a state to prove beyond a reasonable doubt all elements of the offense with which the defendant is charged. ${ }^{195}$ This result highlights the obvious inconsistency between barring an allocation of the burden of persuasion to the defendant yet permitting in Model Penal Code $\S 2.08(2)$ what is essentially a codified irrebuttable presumption. ${ }^{198}$ It also illustrates the general danger of constitutionalizing such procedural preferences and thus limiting the kinds of reforms that a legislature may attempt.

One way of avoiding the Mullaney-Patterson trap is to retain the state's traditional burden of proof on elements of an offense, but to create a separate, affirmative defense that the defendant has the burden of proving. ${ }^{197}$ Commentators have already proposed the essential ingredients to such a scheme in the use of intoxication as a failure of proof defense. Professors J. C. Smith and Glanville Williams, in their proposal to the Criminal Law Revision Commission in England, suggest that an actor who is found nonculpable of an underlying offense because of his intoxication should be convicted of the proposed crime of "Dangerous Intoxication." "198

Although it was perhaps inspired by moral or ethical concerns, ${ }^{109}$

that the defendant was more than reckless, i.e., that he acted either purposely or knowingly with respect to causing death at the time he became intoxicated.

193421 U.S. 684 (1975).

504 432 U.S. 197 (1977).

19s See supra note 51.

${ }^{186}$ See generally Robinson, Imputed Criminal Liability, supra note 22, at 652-55 (discussing other examples of such codified presumptions).

187 Current law only requires the state to carry the burden of persuasion for some defenses. See $1 \mathrm{P}$. Robinson, Criminal Law Defenses, supra note $18, \S 5$.

${ }^{198}$ See Criminal Law Revision Committee, supra note 167, \$263, at 113-14. The proposal was rejected. Id. ๆ 264, at 114; see also Strafgesetzbuch [StGB] § 330a, translated in G. Fletcher, supra note 27 , at 847 (providing for up to five years of imprisonment of an actor who causes a harm while intoxicated to the point of excuse).

189 Part of its attractiveness may have been that it avoided the process inherent in Model Penal Code $\$ 2.08$ (2) (Proposed Official Draft 1962) ("Intoxication") of "imputing" a culpable state of mind that the defendant did not have. The imputation struck some commentators as illogical or immoral. Compare Director of Pub. Prosecutions v. Morgan, [1975] 2 All 
the Smith-Williams approach is a useful device for circumventing the constitutional burden-of-persuasion problems. Such a maneuver is possible because the constitutional prohibition is based on somewhat questionable criteria: allocation to the defendant is barred for an element of the offense definition but is permitted for an independent "defense." "200 By creating a new offense of "Dangerous Intoxication" or "Committing an Offense While Intoxicated," the legislature may control what is defined as an element of the offense and what as a defense. The offense might be defined as follows:

\section{Dangerous IntoXication}

(1) Definition of Offense. An actor who would have been guilty of the offense charged or any lesser included offense but for the defense of intoxication negating an element, as provided in Section xxx [Intoxication Negating an Element], is guilty of the offense of Dangerous Intoxication.

\section{A subsequent subsection might provide:}

(2) Affirmative Defense. It shall be an affirmative defense to the offense of Dangerous Intoxication that the actor proves that at the time he was intoxicating himself he did not have the culpability required by any offense or lesser included offense for which he

\footnotetext{
E.R. 347,360 (Hailsham, L.J.) (logic requires jury instruction permitting a finding that intoxication negates any element of offense) with Director of Pub. Prosecutions v. Majewski, [1976] 2 All E.R. 142, 157 (Salmon, L.J.) (logical principle that prosecution must prove every element of offense cannot prevail where defendant's voluntary intoxication has caused the absence of an element) and id. at 166-68 (Edmund-Davies, L.J.) (same); see also id. at 168-71 (Edmund-Davies, L.J.) (recognizing but rejecting moral objections to conviction absent required culpable state of mind).

For discussion of the illogic of conviction absent proof of a required element, see G. Williams, Criminal Law $\S 181$ (2d ed. 1961); Model Penal Code $\S 2.08$ comment 3 (Tent. Draft No. 9,1959 ). For a discussion of the moral implication of such a conviction, see J. Smith \& B. Hogan, Crimina] Law 37 (3d ed. 1973) (arguing that the voluntarily intoxicated actors who cannot control their conduct should not be punished). It is unprincipled imputation, and not imputation itself, however, that is illogical and immoral. See Robinson, Imputed Criminal Liability, supra note 22 , at $639-42$. The imputation that occurs in $\S 2.08(2)$ and other rules governing voluntary intoxication is no different in function and effect than the imputation that occurs in a host of other accepted criminal law rules and doctrines. See id. at $611-29$.

${ }^{200}$ See Patterson, 432 U.S. at 210,215 (state must prove all of the elements included in the definition of the offense beyond a reasonable doubt, but it need not disprove all affirmative defenses related to culpability).
} 
gained a defense under Section xxx [Intoxication Negating an Element].

With this structure, the constitutional burden-of-persuasion requirement would be satisfied, yet liability in intoxication cases of failure of proof would be imposed according to the theoretically appropriate criterion: the actor's culpable state of mind as to the offense at the time of becoming intoxicated. The defendant, moreover, would have an opportunity, which he now lacks, to escape or reduce his liability when appropriate. ${ }^{201}$ This latter point is significant. Although the Patterson Court suggested that it would disapprove legislative attempts to shift the burden of persuasion to the defendant by gerrymandering the line between offenses and defenses, ${ }^{202}$ the Court also suggested that a shift in the burden might be permissible when the legislature is also providing a new or expanded defense. ${ }^{203}$

This or similar compromise approaches may solve the difficulties of proof, but they substantially exacerbate the complexity problem. Juries are likely to have trouble applying rules governing such technical offenses as "Dangerous Intoxication," which are so artificial and so foreign to the analysis dictated by their sense of justice.

${ }^{201}$ In most jurisdictions, the defendant may never use voluntary intoxication to disprove recklessness. In others, evidence of voluntary intoxication may be unavailing even to dis. prove higher degrees of culpobility. See supra note 45 .

${ }^{202}$ Patterson, 432 U.S. at 210-11.

${ }^{203}$ Id. at 207-08. An interesting question is whether, in deciding that the legislature has offered a "new or expanded" defense, the court will consider the general historical availability of the defense, or the actual historical availability of the defense in the particular jurisdiction. Hawaii, for example, allows a defendant to use voluntary intoxication to negate recklessness. Hawaii Rev. Stat. § 702-230(1) (1976). If Hawaii and Virginia (which considers voluntary intoxication only in capital cases) both passed the legislation outlined above, would the Court uphold Virginia's statute while striking down Hawaii's, on the theory that Hawaii was not offering the defendant any advantage to offset the shift in burden of proof? This result would deter legislators from enacting sweeping reforms for fear that they could never make only a partial retreat.

Outside the failure of proof area, a similar case for constitutional validity might run as follows: many jurisdictions deny a general defense if the actor caused the defense conditions. See statutes and cases supra notes 8-11, 16-20. Others deny such defenses if the actor was "at fault." See statutes and cases supra notes 27, 33. Even in the latter jurisdictions, the defendant need perhaps be at fault only as to causing the defense, and not as to the offense itself. A proposed statute that creates a new offense, "Creating the Conditions of a Defense," but allows an affirmative defense of lack of culpability as to the underlying substantive offense, may well offer such defendants expanded opportunities at exculpation. 


\section{Conclusion}

There are practical limits on constructing workable criminal law doctrine by using our collective sense of justice as a guiding principle. As long as the theory and doctrine approximate this collective sense, however, the limits will be primarily difficulties of proof and not complexity. The proof problems may be solved by various evidentiary devices, such as rebuttable presumptions, which do not distort the theory. Because such nondistorting evidentiary devices appear to be unavailable in the United States, the problems of proof can be solved only by devising doctrines that no longer reflect our collective sense of justice, and therefore no longer are easily understood and implemented by juries. It is thus the constitutional constraints on solving the evidentiary problems that represent the greatest limitation on translating good theory into workable doctrine. Under these constraints, we are condemned to a system of substantive criminal law doctrine that is either unjust or unworkable. 